\title{
La competencia civil de los juzgados de violencia sobre la mujer
}

\author{
Ainhoa Gutiérrez Barrenengoa \\ Profesora doctora de Derecho procesal \\ Universidad de Deusto
}

Recibido: 13.02 .09

Aceptado: 04.05.09

Resumen: Una de las novedades más destacadas de la Ley Orgánica 1/2004, de 28 de diciembre, de Medidas de Protección Integral contra la Violencia de Género viene constituida por la introducción de unos órganos judiciales de nueva creación, denominados Juzgados de Violencia sobre la Mujer, a los que corresponde, de manera exclusiva y excluyente, el conocimiento de los actos de violencia de género $y$, acumuladamente, diversas pretensiones de naturaleza civil, con el fin de proporcionar a la mujer víctima una protección integral.

Durante los años de funcionamiento de estos órganos se han producido numerosos conflictos competenciales con los órganos civiles que tradicionalmente conocían de las materias civiles que ahora se sustraen de su conocimiento y que han puesto de manifiesto, en determinados casos, la insuficiencia de la normativa actual para su resolución, y la necesidad de una reforma legislativa que ponga fin a la división doctrinal y jurisprudencial que ha originado. En el presente trabajo, se abordan especialmente dichos supuestos conflictivos apuntando posibles soluciones para ellos.

Palabras clave: Juzgados de violencia sobre la mujer; competencia judicial, conflictos de competencia.

Abstract: One of the most remarkable novelties introduced by the Organic Law 1/2004, $28^{\text {th }}$ of December 2004, which regulate the measures of integral protection against gender-based violence, is the incorporation of a new type of judicial bodies. These new created judicial branches are called "Courts of violence against women", and are appointed to resolve all the conflicts related to domestic violence, and accumulatively, several civil law suits with the purpose of providing violence victim women, an integral protection, on an exclusive and excluding basis.

During the first years in which these judicial branches have been working, many matters involving the jurisdictional authority have appeared between these new type of courts and the civil judicial bodies, as the late ones traditionally had been resolved the civil issues that with the new law are being retrieved and removed from their jurisdiction. These matters have evidenced, in some cases, the insufficiency of legal resources of the present regulation to solve the jurisdictional controversies aroused. Besides, they have showed the clear necessity of a legal modification in order to put an end to the discussion and division among the legal doctrine and divergent jurisprudence created related to that topic. This paper allows a comprehensive approach of these conflictive cases and their possible solutions.

Key words: Courts of violence against women; judicial competition; conflicts of competition. 
Sumario: I. Los juzgados de violencia sobre la mujer. Idea general.-II. Fundamento de su creación.--III. Críticas a su implantación.IV. Competencia objetiva civil de los juzgados de violencia sobre la mujer. 1. Criterios de atribución. 2. Desaparición sobrevenida de alguno de los presupuestos determinantes de la atribución competencial. 3. Asuntos civiles atribuidos a los juzgados de violencia sobre la mujer.-V. Conflictos de competencia entre los juzgados civiles y los juzgados de violencia sobre la mujer. Regulación y cuestiones que se suscitan. 1. Planteamiento. 2. Procedimiento civil iniciado con anterioridad a la incoación de un proceso penal o a la emisión de una orden de protección. Pérdida de la competencia del juzgado civil. 2.1. Inhibición de oficio del juez civil por incoación del proceso penal o emisión de orden de protección. 2.1.1. Regulación de la inhibición. 2.1.2. Especial referencia al límite temporal para la inhibición. 2.2. Requerimiento de inhibición. 2.3. Supuesto previsto en el apartado segundo del artículo 49 bis de la ley de enjuiciamiento civil. 3. Procedimiento penal $\mathrm{u}$ orden de protección anterior a la interposición de la demanda civil. 3.1. Supuesto en el que el procedimiento penal está tramitándose. 3.2. Procedimiento penal finalizado por sentencia absolutoria o auto de sobreseimiento. 3.3. Procedimiento penal finalizado por sentencia condenatoria. 4. Supuesto de interposición de dos demandas civiles en un juzgado civil y en un juzgado de violencia sobre la mujer. 4.1. Supuesto en el que una de las partes interpone la demanda civil ante el juzgado civil ordinario con posterioridad a la presentación de la demanda, con idéntica pretensión, por la otra parte ante el juzgado de violencia sobre la mujer. 4.2. Supuesto en el que la demanda ante el juzgado civil se presentó con anterioridad a la idéntica presentada ante el órgano especializado.-VI. Competencia funcional.-VII. La competencia territorial.

\section{Los juzgados de violencia sobre la mujer. Idea general}

El 28 de enero de 2005 entró en vigor la Ley Orgánica 1/2004, de 28 de diciembre, de Medidas de Protección Integral contra la Violencia de Género $^{1}$, a excepción de los títulos IV y V, que lo hicieron el 29 de junio de ese mismo año. Una de las novedades más destacadas de la citada ley viene constituida por la introducción de unos órganos judiciales de nueva creación, denominados juzgados de violencia sobre la mujer; los Capítulos I a IV del Título V (arts. 43 a 69) se dedican a la regulación de dichos juzgados, así como a las normas procesales que han de regir sus actuaciones.

${ }^{1}$ BOE núm. 313, de 29 de diciembre de 2004; rect. BOE núm. 87, de 12 de abril de 2005 (RCL 2004, 2661 y RCL 2005, 735). 
Los juzgados de violencia sobre la mujer se configuran como juzgados de instrucción especializados, si bien, desde el punto de vista de la competencia, tienen una competencia mixta que abarca materias de dos órdenes jurisdiccionales distintos, el penal y el civil ${ }^{2}$, ya que estos juzgados conocerán de la instrucción, y, en su caso, del fallo de las causas penales en materia de violencia sobre la mujer, así como de aquellas causas civiles relacionadas, de forma que unas y otras en la primera instancia sean objeto de tratamiento procesal ante la misma sede.

De acuerdo con lo dispuesto en el artículo 87 bis de la Ley Orgánica del Poder Judicial ${ }^{3}$, adicionado por el artículo 43 de la Ley Orgánica 1/2004, los juzgados de violencia sobre la mujer tienen como demarcación el Partido Judicial, con sede en la capital de aquel y jurisdicción en todo su ámbito territorial, tomando su designación del municipio de su sede.

No obstante lo anterior, excepcionalmente, pueden establecerse en otras poblaciones o abarcar dos o más Partidos dentro de una misma provincia (art. 87 bis. 2 LOPJ) o bien, puede el Consejo General del Poder Judicial, previo informe de las Salas de Gobierno, acordar que, en aquellas circunscripciones donde sea conveniente en función de la carga de trabajo existente, el conocimiento de los asuntos referidos en el art. 87 ter LOPJ, corresponda a uno de los juzgados de primera instancia e instrucción, o de instrucción en su caso, y se determina en esta situación que uno solo de estos órganos conozca de todos estos asuntos dentro del Partido Judicial, ya sea de forma exclusiva o conociendo también de otras materias (art. 87 bis 3 LOPJ). A estos efectos, el artículo 52 de la Ley Orgánica 1/ 2004 adiciona a la Ley 38/1988, de Demarcación y Planta Judicial de 28 de diciembre de $1988^{4}$ un nuevo artículo 46 ter, que indica cómo debe efectuarse la adaptación nece-

${ }^{2}$ El apartado séptimo del artículo 544 ter LECrim, introducido por la Ley 27/2003 de 31 de julio, reguladora de la orden de protección de las víctimas de la violencia doméstica (BOE núm. 183, de 1 de agosto de 2003), ya atribuye competencias civiles a un órgano jurisdiccional de carácter penal, como es el juzgado de instrucción, si bien limitadas a determinadas medidas que se pueden acordar provisionalmente en la orden de protección, cuando existan hijos menores o incapaces. Sin embargo, estas medidas tendrán una vigencia temporal de treinta días. Si dentro de este plazo fuese incoado a instancia de la víctima o de su representante legal un proceso de familia ante la jurisdicción civil, las medidas adoptadas permanecerán en vigor durante los treinta días siguientes a la presentación de la demanda. En este término las medidas deberán ser ratificadas, modificadas o dejadas sin efecto por el juez de primera instancia que resulte competente. Por tanto, no se produce una sustracción de atribuciones de los juzgados de primera instancia, a favor de los juzgados de instrucción, a diferencia de lo que ocurre en relación con los juzgados de violencia sobre la mujer.

${ }^{3}$ BOE núm. 157, de 2 de julio de 1985; rect. BOE núm. 264, de 4 de noviembre (RCL $1985,1578$ y 2635$)$.

${ }^{4}$ BOE núm. 313, de 30 de diciembre; rect. BOE núm. 122, de 23 de mayo de 1989 (RCL 1988, 2606 y RCL 1989, 1150). 
saria para la asunción de las funciones propias de los juzgados de violencia sobre la mujer ${ }^{5}$.

En los partidos judiciales en que exista un solo juzgado de primera instancia e instrucción será este el que asuma el conocimiento de los asuntos a los que se refiere el artículo 87 ter LOPJ, compatibilizándolos con el resto de las competencias que tienen legalmente atribuidas (art. 87 bis 4 LOPJ) ${ }^{6}$.

A la vista de lo expuesto hasta el momento, cabe afirmar que, en realidad, la especialización competencial, bien con carácter exclusivo y excluyente, bien con carácter no exclusivo pero sí excluyente, se produce en aquellos casos en los que el conocimiento de los asuntos referidos en el artículo 87 ter LOPJ se atribuye a juzgados de primera instancia e instrucción, o de instrucción ${ }^{7}$. En el resto de los casos, estamos ante órganos de nueva creación, sin perjuicio de ser competencialmente especializados.

${ }^{5}$ Dispone el artículo 46 ter, 1 de la Ley de Demarcación y Planta Judicial que «El Gobierno, dentro del marco de la Ley de Presupuestos Generales del Estado, oído el Consejo General del Poder Judicial y, en su caso, la Comunidad Autónoma afectada, procederá de forma escalonada y mediante Real Decreto a la constitución, compatibilización y transformación de Juzgados de Instrucción y de Primera Instancia e Instrucción, para la plena efectividad de la Planta de los Juzgados de Violencia sobre la Mujer». En cumplimiento de estas previsiones, el Real Decreto 233/2005 de 4 de marzo, modifica el Anexo XIII de la Ley de Demarcación y Planta Judicial, para adaptar los juzgados de violencia sobre la mujer a la programación del año 2005.

${ }^{6}$ Establece en este sentido el artículo 15 bis de la Ley de Demarcación y Planta Judicial de 28 de diciembre de 1988 :

1. «La planta de los Juzgados de Violencia sobre la Mujer será la establecida en el anexo XIII de esta Ley».

2. «La concreción de la planta inicial y la que sea objeto de desarrollo posterior, será realizada mediante Real Decreto de conformidad con lo establecido en el artículo 20 de la presente Ley se ajustará a los siguientes criterios:

a) Podrán crearse Juzgados de Violencia Sobre la Mujer en aquellos Partidos Judiciales en los que la carga de trabajo así lo aconseje.

b) En aquellos partidos judiciales en los que, en atención al volumen de asuntos no se considere necesario el desarrollo de la planta judicial, se podrán transformar algunos de los Juzgados de Instrucción y de Primera Instancia e Instrucción en funcionamiento, en Juzgados de Violencia sobre la Mujer.

c) Asimismo, cuando se considere, en función de la carga de trabajo, que no es precisa la creación de un órgano judicial específico, se determinará, de existir varios, qué Juzgado de Instrucción o de Primera Instancia e Instrucción, asumirá el conocimiento de las materias de violencia sobre la mujer en los términos del artículo 1 de la Ley Orgánica de Medidas de Protección Integral contra la Violencia de Género sin carácter exclusivo junto con el resto de las correspondientes a la jurisdicción penal o civil, según la naturaleza del órgano en cuestión».

${ }^{7}$ En este sentido, señala EsCALADA LóPEZ que estamos ante la creación de un órgano nuevo, y se base fundamentalmente en que su implantación ha supuesto la reforma del artículo 26 LOPJ, en el que se enuncian los juzgados y tribunales tipo, orgánicamente ordinarios, norma en la que, como señala la autora citada, «no existe referencia alguna a aquellos órganos que, siendo orgánicamente ordinarios, devienen ulteriormente especiales o 
Los magistrados y jueces de los juzgados de violencia sobre la mujer serán sustituidos por los juzgados de instrucción o juzgados de primera instancia e instrucción, según el orden que establezca la Sala de Gobierno del Tribunal Superior de Justicia respectivo ${ }^{8}$.

En las actuaciones que constituyen el servicio de guardia conforme al artículo 40 del Reglamento 5/1995 del Consejo General del Poder Judicial, el juez de instrucción que atiende el servicio de guardia actúa en sustitución del juzgado de violencia sobre la mujer.

Habrá que tener en cuenta, por último, la Instrucción 3/2003 de 9 de abril del Pleno del CGPJ sobre normas de reparto penales y registro informático de violencia doméstica ${ }^{9}$ que, como complemento de lo dispuesto en la Ley $38 / 2002$ de 24 de octubre ${ }^{10}$, pretende centralizar en un mismo juzgado todas las denuncias que pueda presentar la víctima para conseguir la aplicación de la habitualidad delictiva en este tipo de delitos. Por tanto, el juzgado de violencia sobre la mujer será competente para conocer de todos los ulteriores procesos penales que, con equiparable objeto y mismos sujetos, puedan incoarse en el futuro, asumiendo la competencia para cualquier actuación propia del proceso civil.

\section{Fundamento de su creación}

En la adopción de la medida de creación de estos órganos judiciales especializados o, en su caso, de especialización de los ya existentes, subyacen en palabras de FUENTES SORIANO ${ }^{11}$ fundamentalmente dos razones: por una parte, «la necesidad de hacer frente de manera especializada y omnicomprensiva a un problema, cual es la violencia de género, cuyas diversas manifestaciones concita en torno a él conflictos de carácter penal, y de carácter

especializados desde un punto de vista competencial, ergo, la mención a los Juzgados de Violencia sobre la Mujer en este art. 26 LOPJ, refuerza la idea de que constituyen un órgano distinto de los Juzgados de Instrucción, y no presuntos Juzgados de Instrucción competencialmente especializados». (EscAlada LóPEz, M. ${ }^{a}$ Luisa, Sobre el Juez ordinario predeterminado por la Ley, Tirant lo blanch, Valencia, 2007, p. 492).

${ }^{8} \mathrm{Cfr}$. art. 211.3 LOPJ, adicionado por la disposición adicional 10. ${ }^{\mathrm{a}}$ de la LO 1/2004.

${ }^{9}$ Vid. en relación con dicha instrucción, MAGRO SERVET, Vicente, «La Instrucción 3/2003 de 9 de abril del CGPJ sobre normas de reparto penales y registro informático de violencia doméstica», Diario La Ley, núm. 5784, Sección Doctrina, 20 de mayo de 2003, Año XXIV, Ref. D-119.

${ }^{10}$ Ley 38/2002, de 24 de octubre, de reforma parcial de la Ley de Enjuiciamiento Criminal, sobre procedimiento para el enjuiciamiento rápido e inmediato de determinados delitos y faltas, y de modificación del procedimiento abreviado (BOE 28 de octubre; rect. BOE 23 de noviembre de 2002).

${ }^{11}$ Fuentes Soriano, Olga, «La constitucionalidad de la Ley Orgánica de medidas de protección integral contra la violencia de género», Diario La Ley, núm. 6362, 2005, Tomo 5, Ref. D-268, p. 1165. 
civil (e incluso en ocasiones asistencial o laboral) que conviene enjuiciar de forma conjunta. Y, por otro lado, el incremento constante de este tipo de violencia así como su gravedad, que requería la creación de unos órganos cualitativamente especializados y suficientes en número».

Efectivamente, se trata de una decisión acorde con el objetivo de fomento de la especialización que, para todos los colectivos profesionales que intervienen en el proceso de información, atención y protección de las víctimas, propugna el artículo $2 \mathrm{j}$ de la LO $1 / 2004^{12}$ y que resulta imprescindible para lograr un tratamiento integral de la violencia de género, tal como se pone de manifiesto en la Recomendación R 13 (85) del Comité de Ministros del Consejo de Europa sobre la violencia en la familia, que señala como necesaria la existencia de juzgados especializados y la racionalización de las normas de reparto, con el fin de mejorar el rendimiento judicial frente al fenómeno del maltrato.

En relación con dicha especialización, cabe recordar que ya existen precedentes con la aprobación por el Pleno del Consejo General del Poder Judicial el 1 de diciembre de 1999 de la especialización de los juzgados de instrucción número 4 de orihuela, y el juzgado de primera instancia e instrucción número 5 de Elche y Alicante con el objeto de atribuirles la instrucción de todos los asuntos relacionados con la violencia doméstica. Dicha especialización se acordó con exención de reparto en algunas materias, pero conservando el resto de las competencias ${ }^{13}$.

La opción por una reforma legislativa que introdujera en el artículo 26 LOPJ estos órganos había sido valorada positivamente por MAGRO SERVET, como única vía para extender la experiencia piloto de los tres juzgados de la provincia de Alicante evitando, en cada caso, el procedimiento de espe-

${ }^{12}$ En este sentido señala la Exposición de Motivos de la citada Ley Orgánica que «... se ha optado por una fórmula de especialización dentro del orden penal, de los Jueces de Instrucción, creando los Juzgados de Violencia sobre la Mujer y excluyendo la posibilidad de creación de un orden jurisdiccional nuevo o la asunción de competencias penales por parte de los Jueces Civiles». La especialización no es, sin embargo, el único objetivo de esta atribución competencial sino que la propia Exposición de Motivos de la LO 1/2004 afirma que la atribución de competencia objetiva para las causas civiles relacionadas con las causas penales en materia de violencia sobre la mujer persigue asegurar «la mediación garantista del debido proceso penal en la intervención de los derechos fundamentales del presunto agresor, sin que con ello se reduzcan lo más mínimo las posibilidades legales que esta Ley dispone para la mayor, más inmediata y eficaz protección de la víctima, así como los recursos para evitar reiteraciones en la agresión o la escalada de la violencia». Con carácter general, sobre los aspectos fundamentales de esta Ley Orgánica se puede consultar CARBALLO Cuervo, Miguel Ángel, «Estudio sobre la Ley Orgánica de Medidas de Protección Integral contra la Violencia de Género», Violencia doméstica, SEPIN, Madrid, 2005, pp. 11-78.

${ }^{13} \mathrm{Vid}$. en relación con dicho procedimiento de especialización MAGRo SERVET, Vicente, «Los nuevos Juzgados especializados de violencia doméstica», Diario La Ley, núm. 4954, de 22 de diciembre de 1999, Tomo 4, Ref. D-124. 
cialización previsto en los artículos 17 y 18 del Reglamento 5/1995 de 7 de junio, de Aspectos Accesorios de la Carrera Judicial ${ }^{14}$.

\section{Críticas a su implantación}

La creación de los juzgados de violencia sobre la mujer no ha estado, sin embargo, exenta de críticas, que van desde el cuestionamiento de la conveniencia de su instauración o de la asignación de competencias civiles ${ }^{15}$, pasando por otras de carácter práctico, en relación con el número insuficiente de juzgados creado y el volumen excesivo de trabajo ${ }^{16}$, hasta otras más graves, al haberse cuestionado su constitucionalidad, puesto que se considera que se trata de una jurisdicción especial ratione personae.

En este sentido, el informe emitido por el Consejo General del Poder Judicial durante la tramitación parlamentaria de la LO 1/2004 llega a calificarlos de juzgados de excepción. En esta línea, Del Pozo PÉrez ${ }^{17}$ pone de

\footnotetext{
${ }^{14}$ En virtud de lo dispuesto por el artículo 17 del Reglamento 5/1995 de 7 de junio, «el acuerdo de especialización podrá adoptarse a iniciativa de las Juntas de Jueces, de las Salas de Gobierno y del propio Consejo General del Poder Judicial. La que proceda de las Juntas de Jueces se elevará por conducto de la Sala de Gobierno correspondiente y con su informe, al Consejo General del Poder Judicial».

De acuerdo con el artículo 18 del citado Reglamento «la propuesta que se eleve al Consejo General del Poder Judicial deberá ser suficientemente motivada e incorporará los antecedentes necesarios, así como un informe sobre la situación y funcionamiento de los órganos judiciales afectados y deberá contener un análisis de la incidencia que el acuerdo de especialización pueda tener sobre otros Tribunales o Juzgados».
}

El artículo 19 de dicha norma establece lo siguiente:

«1. La propuesta será presentada por la Comisión Permanente del Consejo General del Poder Judicial, la cual podrá recabar todos aquellos informes que estime convenientes. Necesariamente deberá recabar el informe de la Sala de Gobierno si no constare, el del Servicio de Inspección y el del Gabinete Técnico.

2. En la petición de los informes, que deberán ser emitidos en el plazo máximo de veinte días, contados a partir de la recepción del escrito, se concretarán el extremo o extremos acerca de los cuales se solicita el informe».

${ }^{15}$ En este sentido, se ha criticado que los Juzgados de violencia sobre la mujer asuman el conocimiento de determinados procesos de familia, ya que la ubicación de estos procesos en sede penal «refuerza una visión punitiva de estos procesos que es incompatible con la finalidad pacificadora de los conflictos familiares que deben tener todos los procesos de familia». Vid. SAnahuja, María, «Juzgados de Violencia sobre la Mujer», La Ley de medidas de protección integral contra la violencia de género, en Cuadernos penales José María Lidón, núm. 2, Universidad de Deusto, Bilbao, 2005, p. 63. Para esta magistrada, los juzgados de violencia sobre la mujer deberían asumir exclusivamente las competencias penales y, en materia civil, las medidas provisionales urgentes derivadas de la orden de protección.

${ }^{16}$ Vid. SanAhuJa, María, «Juzgados de Violencia sobre la Mujer», op.cit., p. 64.

${ }^{17}$ Del Pozo PÉREz, Marta, «Algunos recelos en torno a la regulación procesal de la Ley Orgánica 1/2004 de medidas de protección integral contra la violencia de género», Diario La Ley, núm. 6402, 2006, Tomo 1, D-16, p. 1.273. A juicio de esta autora, los juzgados especializados en esta materia deberían haberse denominado de otra manera (por ejemplo, 
manifiesto que podría producirse con el nuevo órgano jurisdiccional una colisión con el principio de igualdad o con la prohibición de los tribunales de excepción. Esta autora considera que «resulta inadmisible que la necesaria especialización no se haya producido para el conocimiento de la totalidad del conjunto de conductas que integran el complejo fenómeno de la violencia familiar; la creación de nuevos órganos jurisdiccionales no puede producirse para la atribución de competencias determinadas por el sexo de la víctima o la intención del agresor; dicha justificación resulta intolerable en un Estado social y democrático de Derecho que prohíbe la discriminación por razón de edad, sexo o condición».

En mi opinión, sin embargo, la creación de estos órganos cumple todos los requisitos exigidos por el derecho al juez ordinario predeterminado por la ley, garantizado en el artículo 24.2 de la Constitución Española, sin que puedan ser considerados como una jurisdicción especial ${ }^{18}$. A este respecto, cabe recordar que de la doctrina del Tribunal Constitucional relativa al contenido del derecho al Juez ordinario predeterminado por la ley se deduce que encierra una triple garantía:

Por un lado, el órgano judicial ha debido ser creado por una ley en sentido estricto, en la cual se le inviste de jurisdicción y competencia. La STC 93/1988, de 24 de mayo de 1988 (213/1988), FJ 4. ${ }^{\circ}$, recuerda que «en relación con el rango de la norma en que han de contenerse dichos criterios generales, el Tribunal se ha pronunciado en el sentido de entender que se trata de ley en sentido estricto, como resulta tanto de la dicción literal del precepto como de su interpretación sistemática». Así en la STC 101/1984 de 8 de noviembre, este Tribunal afirmó que «la referencia del artículo 24.2 a la

juzgado de violencia familiar o doméstica) y ocuparse de todo tipo de cuestiones relacionadas con la violencia familiar, con independencia del sexo o la condición de su sujeto pasivo. Parece, concluye, «que se crea un órgano jurisdiccional especial para la mujer, cuestión vedada por la CE».

${ }^{18}$ Así lo entienden igualmente Fuentes Soriano, Olga, «La constitucionalidad de la Ley Orgánica de medidas de protección integral contra la violencia de género», cit., pp. 1165 y 1166.

Ciertas dudas parece tener EsCALADA LÓPEZ, para quien «la actual conformación legal de estos juzgados se traduce en que, si bien son creados y les es atribuida jurisdicción por ley, con anterioridad, generalidad y de forma dadora de independencia, su competencia es distribuida por ley (dudosamente constitucional), previa, pero facultadora de la postdeterminación derivada de parciales atracciones de competencias civiles, operadas por el juez penal y, por tanto, de forma excluyente de la abstracta imparcialidad. Ello es así, como consecuencia de la posibilidad de que la parte pueda provocar la postdeterminación competencial, con carácter específico (ad hoc) y crónico, de tal competencia insconstitucionalmente postdeterminada de modo concreto». Todo ello, a juicio de esta autora, «agravado, además, como consecuencia de las específicas normas de reparto por antecedentes, y la consagración de un sumario indefinido». (ESCALADA LóPEZ, María Luisa, Sobre el Juez ordinario..., cit., p. 496). 
ley coherente con lo también dispuesto en los arts. 53.1 y 86.1 de la Constitución, exige que el vehículo normativo para determinar cuál será el juez del caso es la ley en sentido estricto» y ello porque (...) «la interpretación sistemática entre el art. 24.2 y el 117.3, ambos de la Constitución, pone de manifiesto que la garantía de la independencia e imparcialidad de los jueces, que constituye el interés directo protegido por el derecho al juez ordinario predeterminado (...) radica en la ley». La referencia expresa a la ley que lleva a cabo el art. 24.2 CE se corresponde así con la reserva de ley que efectúa el art. 53.1 y la reserva similar contenida en el art. 117.3, y refleja, en relación con la fijación de las reglas fundamentales de la competencia material y territorial, una exclusión de otras normas -decretos leyes o disposiciones de carácter reglamentario- distintas de la ley en sentido estricto, por cuanto que esta se configura como la garantía de la independencia e imparcialidad judicial. Al integrar el contenido del derecho en cuestión la predeterminación por ley del juez competente, es claro que la intervención del decreto ley en este supuesto supone, no solo una afectación de ese derecho prohibida por el art. 86.1 CE, sino su misma negación, al excluir su aspecto esencial de este, como es la cualidad de ley formal de la norma que establezca los criterios fundamentales para la determinación de cuál sea el juez competente.

Por otro lado, es necesario que dicha ley sea previa a su actuación, es decir, que, con anterioridad al caso, se contengan legalmente los criterios de determinación que, al aplicarse a cada litigio, permitan establecer cuál es el juzgado o tribunal llamado a conocer del caso ${ }^{19}$, sin que quepa la creación $a d$ hoc, para el conocimiento y resolución del litigio que se somete a su consideración.

Por último, es necesario que su régimen procesal no permita calificarlo como órgano especial o excepcional ${ }^{20}$. Tal como señala ESCALADA LóPEZ ${ }^{21}$, la alusión relativa a los órganos especiales «viene referida a los tribunales excepcionales o extraordinarios, y a los tribunales orgánicamente especiales constitucionalmente no previstos que, en esta medida, se identifican con los extraordinarios o de excepción».

\footnotetext{
${ }^{19}$ En este sentido, la STC 93/1988, de 24 de mayo, FJ 4. ${ }^{\circ}$, señala que «la predeterminación por ley significa la preexistencia de unos criterios, con carácter de generalidad, de atribución competencial, cuya aplicación a cada supuesto litigioso permita determinar cuál es el juzgado o Tribunal llamado a conocer del caso».

${ }^{20}$ La sentencia del Tribunal Constitucional, Sala Primera, 47/1983, de 31 de mayo de 1983, rec. 148/1981, recuerda en su FJ 2. ${ }^{a}$ la exigencia de que «la composición del órgano venga determinada por Ley y que en cada caso concreto se siga el procedimiento legalmente establecido para la designación de los miembros que han de constituir el órgano correspondiente». Vid. en el mismo sentido, entre otras, SSTC 69/2001, de 17 de marzo, FJ 9; 37/2003 de 25 de febrero, FJ 4; 181/2004, de 2 de noviembre, FJ 7 Y 164/2008 de 15 de diciembre de 2008, rec. 1387/2005, FJ 2.

${ }^{21}$ Escalada LóPez, María Luisa, Sobre el Juez ordinario..., op.cit., p. 443, nota a pie de página 807.
} 
Las garantías referidas constituyen los componentes esenciales del principio constitucional del juez legal predeterminado. Sin embargo, cabe mencionar, siguiendo a BARONA VILAR ${ }^{22}$ dos elementos que complementarían los anteriores:

Por un lado, la exigencia de preexistencia a la atribución de un asunto a un tribunal, de unas reglas de reparto en aquellas poblaciones en las que concurran varios tribunales de la misma categoría, si bien, en su predeterminación no se exige ley formal, y su control corresponde exclusivamente a los tribunales de la jurisdicción ordinaria.

Por otro lado, la exigencia de normas previas de asignación de ponencias entre los distintos magistrados que componen los órganos colegiados, cuya aprobación corresponde a las correspondientes Salas de Gobierno.

Considero que los juzgados de violencia sobre la mujer cumplen las exigencias expuestas, en la medida en que se trata de órganos creados por Ley Orgánica, con generalidad y anterioridad al momento de su intervención. Tampoco son tribunales orgánicamente especiales, sino tribunales ordinarios, incardinados en la organización judicial regulada en la LOPJ, sujetos al mismo régimen jurídico que el resto de los integrantes del Poder Judicial. Todo ello sin perjuicio de que se trate de órganos competencialmente especializados, como lo son otros órganos cuya constitucionalidad no se cuestiona, y que, en algunos casos, también asumen el conocimiento de materias propias de más de un orden jurisdiccional ${ }^{23}$.

Cabría plantearse si la utilización del criterio personal, que se aplica cumulativamente con el criterio material, implica una discriminación por razón de sexo, que vulneraría el principio de igualdad consagrado en el artículo $14 \mathrm{CE}$. A este respecto, señala AsEnCio Mellado que «no puede ser considerado excepcional un tribunal por el hecho de que su competencia

${ }^{22}$ Barona Vilar, Silvia, en Escribano Mora, Fernando (coord.), El proceso civil. Doctrina, Jurisprudencia y Formularios, Vol. I, Tirant lo blanch, Valencia, 2001, p. 452.

${ }^{23}$ En este sentido, cabe mencionar, además de los juzgados de primera instancia especializados en virtud de lo dispuesto en el artículo 98 LOPJ, la reciente creación de los juzgados de lo mercantil por la Ley Orgánica 8/2003, de 9 de julio, para la Reforma Concursal (BOE núm. 164, de 10 de julio [RCL 2003, 1747], por la que se modifica la Ley Orgánica 6/1985, de 1 de julio, del Poder Judicial que se configuran en la Exposición de Motivos II de la LO 8/2003 como juzgados especializados dentro del orden jurisdiccional civil si bien precisa que estos extiendan su competencia a aspectos propios del orden jurisdiccional social.

Por otro lado, no debe olvidarse que la acumulación heterogénea de acciones (civil y penal) en aras de la protección más eficaz de la víctima, no es algo nuevo en el proceso penal en el que se produce ope legis, en virtud de lo dispuesto en el artículo 112 LECrim; el artículo 10 del mismo texto legal permite a los perjudicados por un delito o falta «mostrarse parte en la causa y ejercitar las acciones civiles y penales que procedan, según les conviniera». 
venga determinada por la condición de mujer, ya que, lejos de responder esta opción a razones discriminatorias, lo hace atendiendo a una realidad, cual es la violencia ejercida frente a ella en el ámbito determinado por la ley que hunde sus raíces en un fenómeno social que exige respuestas particularizadas, de contenidos diversos y de forma integral. Considerar desigualdad lo que es una consecuencia de ella y negar una respuesta apropiada a una situación que obliga al Estado a actuar con firmeza y a través de mecanismos apropiados y eficaces constituye una opinión, legítima, pero no consciente de la realidad del problema y sus soluciones» ${ }^{24}$.

Desde una perspectiva similar, considera LAURENZO COPELLO que «la exclusión del varón como sujeto pasivo de las figuras agravadas introducidas por la Ley Integral en nada afecta, pues, al art. 14 de la Constitución. Para que fuese posible discutir siquiera la posible constitucionalidad de esta medida sería preciso que la ley privara de esa tutela reforzada a algún colectivo que se encuentre en una situación fáctica semejante a la de las mujeres, una circunstancia que sin duda no concurre en el grupo de los hombres» ${ }^{25}$.

Argumentos semejantes subyacen en el razonamiento de BALLESTEROS Moreno, quien alega como justificación de la existencia de los juzgados especializados en violencia sobre la mujer las estadísticas, la necesidad de que las mujeres dispongan de igualdad en el ejercicio y acceso a la tutela judicial efectiva, de su protección física y psíquica y de todas sus implicaciones. Desde esta perspectiva pone de manifiesto que «la importancia de que los juzgados de violencia sobre la mujer no constituyan una acción de discriminación inversa, radica en que, en primer término, no se afectan los derechos de los varones víctimas de violencia por parte de sus parejas o ex parejas y, por tanto, se debe considerar como una medida acorde con la Constitución, pues su finalidad es lograr principio de igualdad y la tutela judicial efectiva» ${ }^{26}$.

Frente a este tipo de planteamientos, algún autor se cuestiona si existe realmente, en relación con la atribución de competencia a un órgano judicial

\footnotetext{
${ }^{24}$ Asencio Mellado, José María, «La competencia civil de los Juzgados de Violencia sobre la Mujer», La Ley de medidas de protección integral contra la violencia de género, en Cuadernos penales José María Lidón, núm. 2, Universidad de Deusto, Bilbao, 2005, p. 73.

${ }^{25}$ LAURENZO COPELlo, Patricia, «El modelo de protección reforzada de la mujer frente a la violencia de género: valoración político-criminal», La Ley de medidas de protección integral contra la violencia de género, en Cuadernos penales José María Lidón, núm. 2, Universidad de Deusto, Bilbao, 2005, p. 109. Vid. STC, Pleno, 98/2008 de 24 de julio de 2008, rec. 51/2007; STC, Pleno, 83/2008, de 17 de julio de 2008, rec. 5163/2006; STC, Pleno, 59/2008, de 14 de mayo, rec. 5939/2005.

${ }^{26}$ Ballesteros Moreno, Constanza, «Tutela judicial», en Aranda Álvarez, Elviro (dir.), Estudios sobre la Ley Integral contra la Violencia de Género, Dykinson, Madrid, 2005, pp. 141 y 142.
} 
concreto, razones que justifiquen dicha medida en atención a la condición de mujer. En este sentido, hay que tener en cuenta que, en general, las medidas adoptadas se justifican precisamente desde la perspectiva del principio de igualdad consagrado en el artículo $14 \mathrm{CE}$, en su vertiente de igualdad en la ley, desde la consideración de que la regulación diferenciada se establece con base en que los supuestos de hecho son distintos de los que aparecen reflejados en la regulación general ${ }^{27}$. Sin embargo, en este punto concreto se ha señalado que, por un lado, no existe una situación inicial de desventaja que impida o limite de algún modo el acceso a la tutela judicial a las mujeres víctimas de violencia a manos de sus maridos o parejas y, por otro, que la medida de excluir de la competencia de los nuevos juzgados las agresiones padecidas por sujetos distintos, como puede ser el varón o cualquier ascendiente con independencia de su sexo, no proporciona ventaja alguna respecto de la víctima mujer casada o compañera sentimental, sino que «tan solo supone una discriminación negativa respecto a quien no se encuentra amparado por $\operatorname{los} \mathrm{JVM} »^{28}$.

Estos argumentos se rebaten alegando que lo que se pretende es proteger más eficazmente la dignidad de la mujer, acudiendo a mecanismos que garanticen mejor la tutela judicial efectiva, partiendo de que existen desigualdades de inicio. En este sentido, como se ha apuntado, la creación de estos órganos responden a una necesidad social, apoyada en estadísticas judiciales obtenidas y analizadas por el Observatorio contra la Violencia de Género, para que, a través de su especialización, pueda realizarse un seguimiento completo de la problemática en la que vive inmersa cada mujer y los que con ella conviven.

${ }^{27}$ Vid. Fuentes SoRIANO, Olga, «La constitucionalidad de la Ley Orgánica de medidas de protección integral contra la violencia de género», cit., pp. 1160 a 1162.

${ }^{28}$ Cubillo LóPeZ, Ignacio, «Los Juzgados de Violencia sobre la Mujer y la determinación de su competencia», Tutela penal y tutela judicial frente a la violencia de género, Colex, Madrid, 2006, p. 127.

En el Informe del Consejo General del Poder Judicial al Anteproyecto de la Ley Orgánica de Medidas de Protección Integral contra la violencia de género (pág. 25), se señala que «la tutela judicial no es, en cuanto tal, un bien escaso que no permita, por una supuesta limitada disponibilidad, su reparto y atribución a todos cuanto lo precisen; es decir, la tutela judicial es un bien que no exige se excluya de su ámbito a ningún grupo humano (varones en este caso) para dar debida satisfacción a otro grupo más desfavorecido (mujeres en este caso). Por decirlo sintéticamente: existe posibilidad de tutela judicial para todos sin excluir ni postergar, es decir, sin eliminar ni discriminar a nadie. Distinto sería el supuesto de que una limitación legal impusiera un número máximo de asuntos a resolver por los nuevos órganos judiciales, previstos para conocer de la violencia doméstica, y esa limitación exigiera entonces dar prioridad a las mujeres frente a los varones (reparto de un bien escaso, con preferencia del más favorecido). Pero no sucede tal cosa, ni podría suceder en el proyecto que se informa». 
Por todo ello, no se comparten tampoco las críticas vertidas en relación con el riesgo que supone para la imparcialidad el que un mismo juez sea quien instruya unos hechos que pueden constituir a su vez, al menos parcialmente, el objeto del proceso civil sobre el que ha de fallar. En este sentido se señala que esa posible conexión entre el objeto de uno y otro procesos puede provocar que el juzgado de violencia sobre la mujer lleve a cabo, en el proceso penal, determinadas actuaciones y diligencias de investigación que le generen algunos «prejuicios» sobre los hechos ocurridos o en relación con las personas implicadas, las cuales, se añade, podrían condicionarle a la hora de tomar ciertas decisiones en el proceso civil, especialmente aquellas que pueden encerrar un elevado grado de discrecionalidad, apuntándose como ejemplo a quién se atribuye la custodia de los hijos o cuál es el régimen de visitas, entre otras ${ }^{29}$.

En mi opinión, sin embargo, el conocimiento de todos los hechos y circunstancias que puedan concurrir en estos supuestos no debe verse como un inconveniente sino como una necesidad y, especialmente, cuando se trata de adoptar medidas como la mencionada. A este respecto, cabe reiterar que, precisamente, la atribución de competencias civiles a estos órganos jurisdiccionales penales se justifica en la necesidad de otorgar a la mujer víctima de la violencia de género una protección integral, sin que pueda cumplirse dicha finalidad con efectividad si los diversos asuntos tanto penales como civiles, que afectan a su situación familiar y a su relación con el presunto agresor se tramitan ante órganos judiciales distintos, que pueden, incluso, dictar resoluciones contradictorias. Se evita así la tan criticada peregrinación de jurisdicciones que únicamente contribuye a victimizar, por segunda vez, a dicha mujer ${ }^{30}$.

\footnotetext{
${ }^{29}$ Este es el planteamiento de CUBILlo LóPEZ, que cuestiona la constitucionalidad de los juzgados de violencia sobre la mujer, por contravenir el derecho a un juez imparcial en su vertiente objetiva o, en otra terminología, a un juez no prevenido, comprendido dentro del derecho fundamental a un proceso con todas las garantías del artículo 24.2 CE. (CuBILlo LóPEZ, Ignacio, «Los Juzgados de Violencia sobre la Mujer y la determinación de su competencia», op.cit., p. 124).

${ }^{30}$ Vid. en este sentido, Planchadell Gargallo, Andrea, «La competencia del Juez de Violencia sobre la Mujer», en BoIX REIG, Javier y MARTínEz GARCíA, Elena (coords.), $L a$ Nueva Ley contra la Violencia de Género (LO 1/2004, de 28 de diciembre), Iustel, Madrid, 2005, p. 295.
} 


\section{Competencia objetiva civil de los juzgados de violencia sobre la mujer}

\section{Criterios de atribución}

Supuesto un número de órganos judiciales de distinto tipo, las normas sobre competencia objetiva nos indican, teniendo en cuenta el objeto del proceso, qué tipo o clase de órgano judicial, dentro de los que tienen atribuida competencia genérica en el ámbito del orden jurisdicción civil ${ }^{31}$, debe conocer de un determinado asunto, en primera o única instancia.

Tradicionalmente tres son los criterios que, en ocasiones combinados entre sí, ha utilizado el legislador para atribuir este conocimiento: a) el de la persona del demandado; b) el de la materia o naturaleza del asunto; c) el de la cuantía o cantidad objeto de litigio. El criterio de la cuantía es siempre subsidiario, de manera que habrá que estar a lo que resulte de los otros dos, con independencia de a cuánto ascienda el valor de la demanda.

La creación de los juzgados de violencia sobre la mujer exige la combinación de algunos de los criterios mencionados y la incorporación de alguno nuevo. Concretamente, señala GonZÁlEz GRANDA ${ }^{32}$, que, en el caso de los juzgados de violencia sobre la mujer, se combinan para la atribución de competencia objetiva en el ámbito civil tres criterios: a) un criterio cualitativo ratione materiae, asumiendo el conocimiento solo de un elenco de materias previamente enumeradas en el apartado segundo del nuevo artículo 87 ter

${ }^{31}$ Dispone el párrafo segundo del artículo 9 de la LOPJ que «los Tribunales y Juzgados del Orden Civil conocerán, además de las materias que les son propias, de todas aquellas que no estén atribuidas a otro orden jurisdiccional».

«En este orden civil, corresponderá a la jurisdicción militar la prevención de los juicios de testamentaría y de abintestato de los miembros de las Fuerzas Armadas que, en tiempo de guerra, fallecieren en campaña o navegación, limitándose a la práctica de la asistencia imprescindible para disponer del sepelio del difunto y la formación del inventario y aseguramiento provisorio de sus bienes, dando siempre cuenta a la autoridad judicial civil competente».

El artículo 87 ter LOPJ actúa de complemento del artículo 9.3 LOPJ, modificando, a su vez, la previsión del artículo 9.2 LOPJ, al sustraer del conocimiento de los tribunales civiles materias que «les son propias». (SENÉs Motilla, Carmen, «La competencia penal y en materia civil de los Juzgados de Violencia sobre la Mujer», Diario La Ley, núm. 6371, 2005, Tomo 5, Ref. D-279, p. 1269).

32 González Granda, Piedad, «Los Juzgados de Violencia sobre la mujer en la Ley Orgánica de medidas de protección integral contra la violencia de género», Diario La Ley, núm. 6214, 2005, Tomo 2, Ref. D-67, p. 1634; los mismos criterios son referidos por MAGRO SERVET, Vicente, «La competencia en materia civil de los Juzgados de Violencia sobre la Mujer (competencia objetiva, territorial, y funcional)», Práctica de los Tribunales, núm. 19, septiembre 2005, pp. 36 y 37; DELGADO MARTín, Joaquín, «Los Juzgados de Violencia sobre la Mujer», Diario La Ley, núm. 6279, 2005, Tomo 3, Ref. D-155, pp. 1922 a 1924. 
LOPJ; b) un criterio cualitativo ratione personae, siendo necesario además que alguna de las partes del proceso civil sea víctima de los actos de violencia de género en los términos a que hace referencia el apartado $1 .^{\circ}$ del art. 87 ter LOPJ y que alguna de las partes del proceso civil sea imputado como autor, inductor o cooperador necesario en la realización de actos de violencia de género; y c) un criterio de actividad que se traduce en la exigencia de que se hayan iniciado ante el juez de violencia sobre la mujer actuaciones penales por delito o falta a consecuencia de un acto de violencia sobre la mujer, o se haya adoptado una orden de protección a una víctima de violencia de género.

En este sentido, ONTIVEROS RODRÍGUEZ ${ }^{33}$ señala que la competencia objetiva en el orden civil de estos juzgados viene determinada por la concurrencia simultánea de tres presupuestos: un primero de carácter material; un segundo de carácter personal y un tercero de carácter procedimental ${ }^{34}$.

Concretamente, de acuerdo con lo dispuesto en el artículo 87 ter $3 .^{\circ}$ LOPJ, los juzgados de violencia sobre la mujer tendrán de forma exclusiva y excluyente competencia en el orden civil cuando concurran simultáneamente los siguientes requisitos:

a) Que se trate de un proceso civil que tenga por objeto alguna de las materias indicadas en el número 2 del artículo 44 del artículo 87 ter $L O P J^{35}$.

b) Que alguna de las partes del proceso civil sea víctima de los actos de violencia de género, en los términos a que hace referencia el apartado 1 a del artículo 87 ter LOPJ.

Este apartado se refiere concretamente a la instrucción de los procesos para exigir responsabilidad penal por los delitos recogidos en los títulos del Código Penal relativos a homicidio, aborto, lesiones, lesiones al feto, delitos contra la libertad, delitos contra la integridad moral, contra la libertad e indemnidad sexuales o cualquier otro delito cometido con violencia o intimidación, siempre que se hubiesen cometido contra quien sea o haya sido su esposa, o mujer que esté o haya estado ligada al autor por análoga relación de afectividad, aun sin convivencia, así como los cometidos sobre los des-

${ }^{33}$ Ontiveros Rodríguez, Francisco, «Competencia civil de los Juzgados de Violencia sobre la Mujer: el art. 49 bis de la Ley de Enjuiciamiento Civil (problemática y propuestas de reforma), Diario La Ley, núm. 6695, 2007, Tomo 2, Ref. D-95, pp. 1832 y 1833.

${ }^{34}$ SenÉs Motilla alude exclusivamente a un doble requisito: un requisito subjetivo (la condición de parte en el proceso civil de la víctima de violencia de género y de su agresor) y un requisito funcional (la pendencia de un proceso penal por hechos delictivos susceptibles de ser calificados de violencia de género o la adopción de un orden de protección a la víctima). (SEnÉs Motilla, Carmen, «La competencia penal y en materia civil de los Juzgados de Violencia sobre la Mujer», cit., p. 1270).

${ }^{35}$ Vid. epígrafe IV 3 de este trabajo. 
cendientes propios o de la esposa o conviviente, o sobre los menores o incapaces que con él convivan o que se hallen sujetos a la potestad, tutela, curatela, acogimiento o guarda de hecho de la esposa o conviviente, cuando también se haya producido un acto de violencia de género ${ }^{36}$.

A efectos del cumplimiento de este presupuesto es indiferente la posición que ocupe la víctima (tanto la mujer como alguna de las personas a las que hace referencia el art. 87 ter,1 LOPJ) en el proceso civil, concurriendo dicho requisito incluso aunque ambos cónyuges compartan la misma posición procesal ${ }^{37}$.

c) Que alguna de las partes del proceso civil sea imputado como autor, inductor o cooperador necesario en la realización de actos de violencia de género.

Cabe entender que la ley utiliza el término imputado en sentido amplio, sin que la atribución de la competencia civil quede condicionada a la existencia de imputación judicial en forma de auto de procesamiento o resolución equivalente ${ }^{38}$.

A estos efectos, cabe recordar la sentencia del Tribunal Supremo (Sala 2. a) 135/1989, de 19 de julio (RTC 1989, 135) en la que se reconoce la con-

${ }^{36}$ La referencia únicamente a delitos no debe inducir a error en cuanto a la negación de la competencia civil del juzgado de violencia sobre la mujer cuando lo sea penalmente en los supuesto de faltas. En este sentido el AAP de Murcia núm. 23/2006, de 14 de febrero de 2006, señala que «el límite sustantivo en la faceta penal, que es el que aquí interesa, alude claramente a delito y a falta, mientras que el apartado en que se apoya el Juzgado de Violencia se refiere a la delimitación personal, de ahí que la remisión al apartado 1 a) que ordena el art. 87 ter $3 \mathrm{~b}$ ), lo sea a los solos efectos de concretar los sujetos, no los hechos, que vienen establecidos en el apartado d)».

${ }^{37}$ En el caso de que se produzcan agresiones mutuas, entiende AsEncio Mellado que deberán acumularse ante el juzgado de violencia sobre la mujer las pretensiones civiles que se dirijan ambos cónyuges. Estas normas, añade, autorizan al agresor a reconvenir, en el marco del art. 87 ter LOPJ, frente a la demanda interpuesta por la persona víctima de la violencia de género, sin que sea posible la reconvención fuera de la competencia objetiva de los juzgados de violencia sobre la mujer. (Asencio Mellado, José María, «La competencia civil de los Juzgados de Violencia sobre la Mujer», op. cit., p. 77).

${ }^{38}$ En este sentido SENÉs Motilla, Carmen, «La competencia penal y en materia civil de los Juzgados de Violencia sobre la Mujer», cit., pág. 1270; CuBILlo LóPEZ, Ignacio, «Los Juzgados de Violencia sobre la Mujer y la determinación de su competencia», op. cit., pp. 152 y 153. CASTILlejo MANZANARES considera, en esta línea, que el concepto de imputado ha de entenderse equivalente al de denunciado, ya que el precepto mencionado se refiere no solo a procesos por delito sino también a procesos por faltas en los que no existe formalmente un juicio de imputabilidad con anterioridad al acto de la vista. (CASTILlEJo MANZANARES, Raquel, «Cuestiones que suscita la Ley Orgánica de Medidas de Protección Integral contra la Violencia de Género», Diario La Ley, núm. 6290, 2005, Tomo 3, Ref. D-171, p. 2029).

Vid. en relación con la condición de imputado en el procedimiento abreviado, STC, Pleno 186/1990, de 15 de noviembre de 1990, rec. 1914/1990. 
dición de imputado «a toda persona a quien se atribuya, más o menos fundadamente, un acto punible, permitiéndole ejercitar el derecho de defensa en su más amplio contenido, actuando en el procedimiento penal cualquiera que este sea, desde que se le comunique inmediatamente la admisión de la denuncia o querella no de la simple interposición de una u otra, o cualquier otra actuación procesal de la que resulta la imputación de un delito, o haya sido objeto de detención, o de cualquier otra medida cautelar, o se haya acordado su procesamiento, a cuyo efecto se le instruirá en este derecho».

Se ha señalado que cuando el hecho sea constitutivo de falta, será suficiente la mera interposición de la denuncia para entender cumplido este último requisito ${ }^{39}$. Frente a esta opinión, cabría entender que en el juicio de faltas la condición de imputado se adquiere con la citación al plenario como denunciado o eventual responsable penal, momento a partir del cual se produce el traslado de la imputación pudiendo ejercitar el citado su derecho de defensa ${ }^{40}$.

d) Que se hayan iniciado ante el juez de violencia sobre la mujer actuaciones penales por delito o falta a consecuencia de un acto de violencia sobre la mujer, o se haya adoptado una orden de protección a una víctima de violencia de género.

En el caso de los delitos, la combinación de los requisitos exigidos en las letras $c$ y $d$ aconsejaría una mínima actividad procesal, con al menos una resolución judicial, que podría ser la de admisión de la denuncia o querella ${ }^{41}$.

39 Armenteros León, Miguel, «Algunas cuestiones que plantea la competencia de los nuevos Juzgados de Violencia sobre la Mujer», cit., p. 1232.

${ }^{40}$ Delgado Martín, Joaquín, «Los Juzgados de Violencia sobre la Mujer», cit., p. 1923.

${ }^{41}$ SenÉs Motilla considera «necesaria la calificación jurisdiccional de los hechos objeto de la denuncia como delictivos y manifestación de la violencia de género (ex art. 87 ter 1 a LOPJ) seguida de la incoación de las diligencias oportunas (arts. 308, 309 bis, 774 y 797.1 LECrim)». (SENÉS Motilla, Carmen, «La competencia penal y en materia civil de los Juzgados de Violencia sobre la Mujer», cit., p. 1270).

En este sentido, CuBILlo LóPEZ considera que «debe haberse admitido a trámite la pretensión penal, si ha sido formulada a instancia de parte (...). De este modo, se establece un cierto control a fin de evitar aquellas denuncias presentadas ante los JVM sin fundamento y con el único propósito de atribuirles el conocimiento del asunto civil, dada su actuación especializada y presumiblemente más rápida». (CuBILlo LóPEZ, Ignacio, «Los Juzgados de Violencia sobre la Mujer y la determinación de su competencia», op. cit., p. 152).

Señala MUERZA ESPARZA que, por ejemplo, «en el proceso abreviado deberá entenderse “iniciado" el proceso penal, a los efectos que aquí interesa, con carácter general, cuando se incoen las diligencias previas (art. 774 LECrim), que son las diligencias judiciales dirigidas a determinar la naturaleza y circunstancias del hecho delictivo; las personas que en él han participado y el órgano competente para su enjuiciamiento (art. 777 LECrim)». (MUERZA EsParZA, Julio, «Aspectos procesales de la LO 1/2004, de 28 de diciembre», MuerZA EsParza, Julio (coord..), Comentario a la Ley Orgánica de Protección Integral contra la Violencia de Género. Aspectos jurídico-penales, procesales y laborales, Thomson/Aranzadi, Cizur Menor, 2005, p. 59). 
De no exigirse estas mínimas garantías, como pone de manifiesto ARMENTEROS LEÓN ${ }^{42}$, «se podría llegar a la situación de que se atribuya la competencia civil a los juzgados especializados porque se ha interpuesto una denuncia por actos de violencia de género y después resulta que esa denuncia es inadmitida o bien remitida a otro órgano judicial por no ser los hechos competencia de este juzgado». Se ha apuntado, por otro lado, que si fuera suficiente, en todos los casos, la mera interposición de la denuncia, sería mayor el peligro de la posible utilización fraudulenta de denuncias por maltrato para atraer la competencia del juez de violencia sobre la mujer, y la pérdida de la competencia de los juzgados de primera instancia que estuvieren conociendo ${ }^{43}$.

En cuanto al requisito de la adopción de una orden de protección a favor de la víctima, se entenderá cumplido, a efectos de la atribución competencial a favor del juzgado de violencia sobre la mujer, aunque lo haya sido por un juzgado distinto del competente.

\section{Desaparición sobrevenida de alguno de los presupuestos determinantes de la atribución competencial}

La Ley Orgánica 1/2004 guarda silencio en relación con el supuesto en el que, después de que el juzgado de violencia sobre la mujer ha asumido la competencia objetiva para conocer de un concreto proceso de familia, por concurrir los presupuestos exigidos al efecto en el artículo 87 ter LOPJ, se produce la desaparición sobrevenida de alguno de dichos presupuestos, lo que ocurriría especialmente en caso de archivo o sobreseimiento del proceso penal por violencia de género o cuando se dicte en él una sentencia absolutoria.

En relación con dicho supuesto, y sin perjuicio de criticar la solución, Castillejo Manzanares ${ }^{44}$, en los casos en los que el juez de violencia sobre la mujer al inicio de la instrucción archiva casi de forma inmediata las diligencias penales o, más adelante, sobresee el procedimiento, incluso de forma provisional, o dicta sentencia absolutoria, considera que el juez de vio-

\footnotetext{
42 Armenteros León, Miguel, «Algunas cuestiones que plantea la competencia de los nuevos Juzgados de Violencia sobre la Mujer», cit., p. 1232.

${ }^{43}$ Peligro que a juicio de GonZÁLEZ GrANDA es real y que no cabe pensar que quede eliminado simplemente con el posible efecto disuasorio de la apertura de diligencias por denuncia falsa. (GonZÁLEZ GrANDA, Piedad, «Los Juzgados de Violencia sobre la mujer en la Ley Orgánica de medidas de protección integral contra la violencia de género», cit., p. 1634).

${ }^{44}$ Castillejo Manzanares, Raquel, «Cuestiones que suscita la Ley Orgánica de Medidas de Protección Integral contra la Violencia de Género», cit., pág. 2030. Vid. también Planchadell Gargallo, Andrea, «La competencia del Juez de Violencia sobre la Mujer», op. cit., pp. 304 y 305.
} 
lencia sobre la mujer «debe dejar de conocer de todas las causas civiles por faltar el presupuesto de hecho del nuevo art. 87 ter 3 , c, con los que no hallaríamos ante un trasvase de asuntos civiles que resulta conveniente evitar».

En la misma línea, Pérez-Olleros SÁnChez-BordonA ${ }^{45}$ señala que «a los efectos de evitar fraudes y abusos procesales, y elección de Juez, con fundamento en el art. 87 ter. 4, puede entenderse que la competencia se traslada condicionada a que no se dicten en la causa penal una resolución de sobreseimiento o una sentencia absolutoria del acusado firme, que determine que los hechos puestos en su conocimiento no constituyen de forma notoria expresión de violencia de género» $\mathrm{y}$, de así determinarse en la causa penal, entiende que «el JVM remitirá de nuevo el procedimiento civil al órgano que fue por reparto competente».

En mi opinión, atribuida la competencia para conocer del asunto civil al juzgado de violencia sobre la mujer, esta no se pierde por el hecho de que, finalmente, el proceso penal termine mediante resolución absolutoria o cualquier otra que determine el archivo o sobreseimiento de las actuaciones ${ }^{46}$. En este sentido el Auto de la Audiencia Provincial de Madrid (Sección 22.a) de 6 de marzo de 2006 (rec. 161/2006), refiriéndose al artículo 49 bis LECiv en relación con los requisitos que menciona el artículo 87 ter. 3 LOPJ, señala

${ }^{45}$ A juicio de este autor, «esto concuerda con la previsión de que las sentencias que se dicten por los Juzgados Penales o Audiencias Provinciales, cuando la instrucción de la causa hubiera correspondido a un JVM, serán remitidas al mismo por testimonio de forma inmediata, con indicación de si la sentencia es o no firme (art. 160 y 789.5 de la LECrim, reformados por un nuevo párrafo introducido por los arts. 53 y 55 de la LO 1/2004)». (PÉreZ-Olleros SÁnchez-Bordona, Francisco Javier, «Cuestiones y respuestas sobre la Ley Orgánica de Medidas de Protección Integral contra la Violencia de Género», Diario La Ley, núm. 6273, 2005, Tomo 3, Ref. D-140, p. 1839).

${ }^{46}$ GutiérRez Romero, F. M., «Cuestiones de organización y de competencia en la nueva LO 1/2004, de 28 de diciembre, de Protección Integral contra la Violencia de Género: los nuevos juzgados de violencia sobre la mujer», Revista Poder Judicial, núm. 79, 2005, pp. 86 y 87. Se puede consultar también del mismo autor Violencia de género. Fundamentos y práctica procesal, SEPIN, Madrid, 2007.

GisBert POMATA defiende igualmente la conservación de la competencia del juzgado de violencia sobre la mujer que la tenía en el momento de admisión a trámite de la demanda, aunque posteriormente el proceso penal termine por alguna de las posibilidades indicadas. (Gisbert Pomata, Marta, «La especialización de los Juzgados: Juzgados de Violencia sobre la Mujer», Revista de Derecho Procesal, 2006, p. 350). En el mismo sentido se manifiestan Asencio Mellado, José María, «La competencia civil de los Juzgados de Violencia sobre la Mujer», op. cit., p. 84; SENÉS MotILla, Carmen, «La competencia penal y en materia civil de los Juzgados de Violencia sobre la Mujer», cit., p. 1271; Ballesteros Moreno, Constanza, «Tutela judicial», en ArANDA Álvarez, Elviro (dir.), op. cit., p. 142; CuBILlo LóPEz, Ignacio, «Los Juzgados de Violencia sobre la Mujer y la determinación de su competencia», op. cit., p. 159; MARTÍNEZ GARCíA, Elena, La tutela judicial de la violencia de género. Iustel, Madrid, 2008, pp. 111 y 112. 
que «este último precepto (...) no supedita, en modo alguno, el definitivo conocimiento del asunto civil a la suerte de la causa penal, ya que (...), una vez determinada la competencia, en razón de las circunstancias procesales existentes al tiempo de presentarse la demanda, se produce el efecto de la perpetuatio iurisdictionis, lo que excluye, por los posibles avatares ulteriores del procedimiento penal, nuevos cambios de órgano competente, que entrarían en abierta colisión con el derecho fundamental al juez ordinario predeterminado por la ley que consagra el artículo 24.2 de la Constitución», concluyendo que «la desaparición sobrevenida de los condicionantes que determinaron, en su momento, la competencia civil del Juzgado de Violencia, no puede conllevar el que el mismo decline nuevamente la misma, en una viciosa espiral que no viene permitida legalmente». Siguiendo un razonamiento similar en el Auto de la Audiencia Provincial de Barcelona, Sección 19. ${ }^{\text {a }}$, de 6 de junio de 2007 (rec. 380/2007) se establece que «el sobreseimiento y archivo de la causa penal con posterioridad al momento en que procede hacer examen de la competencia, (...), no tiene como efecto la devolución de la competencia al Juzgado de Familia que acordó la inhibición del procedimiento al Juzgado de Violencia en estricta aplicación de lo dispuesto en la Ley de Enjuiciamiento Civil. (...) el sobreseimiento de la causa penal con fecha posterior, no cambia la competencia inicialmente determinada. El procedimiento de divorcio, en cuanto a la competencia objetiva se refiere, no puede depender o quedar supeditado a la suerte final de la causa penal abierta. La competencia queda determinada (...) atendiendo al estado en que se encuentra la causa penal en el momento de presentarse la demanda o lo que es lo mismo, determinada la competencia en función de las circunstancias procesales concurrentes al tiempo de plantearse la demanda civil, se produce el efecto de la perpetuatio iurisdictionis» ${ }^{47}$.

Además del argumento basado en la perpetuatio iurisdictionis, la Guía Práctica de la Ley Orgánica 1/2004 elaborada por el Observatorio contra la violencia doméstica y de género del Consejo General del Poder Judicial añade, para justificar la conservación de la competencia civil por el juzgado de violencia sobre la mujer pese a la desaparición sobrevenida de los presupuestos que motivaron su asunción, a los efectos de evitar una nueva traslatio iudicii o trasvase al juez civil, los siguientes ${ }^{48}$ :

${ }^{47}$ Vid. igualmente, manteniendo la competencia del juzgado de violencia sobre la mujer para conocer del procedimiento civil, aun cuando con posterioridad a la recepción de las actuaciones por dicho juzgado (debiéndose tramitar estas, por el órgano judicial, conforme viene previsto en el art. 770 de la L.E.C.) se hubiera sobreseído la causa penal, el Auto de la Audiencia Provincial de Barcelona (Sección 12.a ), de 31 de enero de 2008, rec. 877/2007.

${ }^{48}$ Vid. en este sentido igualmente Delgado MarTín, Joaquín, «Los Juzgados de Violencia sobre la Mujer», cit., pp. 1926 y 1927. 
a) Que la solución contraria llevaría a una quiebra del principio de economía procesal.

b) Que sería contrario al principio de seguridad jurídica del artículo 9.3 CE, ante la ausencia de una norma legal expresa que permita una modificación de la competencia por alteraciones fácticas sobrevenidas.

c) Que una nueva alteración de la competencia a favor del juzgado de lo civil no prevista legalmente supondría un menoscabo del derecho fundamental al juez ordinario predeterminado por la ley.

d) Que, asimismo, podría afectar al derecho fundamental a un proceso sin dilaciones indebidas (art. 24.2 CE), por el nuevo retraso que puede suponer en la tramitación del procedimiento.

e) Por último, que podría suponer una situación de incertidumbre (asunción de la competencia objetiva de forma condicionada o provisional), que se considera difícilmente aceptable por el Derecho Procesal, posibilitando incluso que determinados actos de las partes puedan influir en la determinación y modificaciones sucesivas de la competencia objetiva; a este respecto se señala que habría espacio suficiente para cierto margen de elección del juez por las partes.

Ahora bien, el riesgo de la intervención de la voluntad de las partes, o de alguna de ellas, en la determinación del juez competente, en este ámbito en el que no solo las normas de competencia objetiva, sino también las que determinan la competencia territorial tienen carácter imperativo, quedando excluida la sumisión tácita o expresa a favor de un juzgado concreto, se plantea también mantenerse la tesis defendida en el texto, que excluye el trasvase judicial en caso de sobreseimiento o sentencia absolutoria.

A este respecto, sin perjuicio de lo expuesto, comparto el criterio de GUTIÉRREZ ROMERO ${ }^{49}$, quien considera que debe existir un límite para evitar posibles fraudes procesales de interponer denuncia penal y así conseguir que el procedimiento civil correspondiente, que se está llevando en otro juzgado, se tramite con mayor celeridad o, cabe añadir, lo que es más grave desde el punto de vista del respeto al derecho al juez ordinario predeterminado por la ley, que se tramite ante un órgano distinto, que, se intuye, puede dictar una resolución más favorable a los intereses de la mujer ${ }^{50}$. Dicha limitación, tal

${ }^{49}$ GutiérRez Romero, F. M., «Cuestiones de organización y de competencia en la nueva LO 1/2004, de 28 de diciembre...», cit., p. 87.

${ }^{50}$ Critica Escalada López la distribución competencial prevista en el artículo 87 ter LOPJ entre otras razones porque, a su juicio, «de la regulación contemplada se deriva la posibilidad de que la mujer que haya incoado un proceso civil sobre alguna de las aludidas materias (separación, divorcio, etc.) y que no se encuentre satisfecha con el juez que la ley le ha atribuido en suerte, o con el tratamiento que este esté dispensando a su caso, pueda presentar una denuncia o solicitar una orden de protección -fundada o no- de modo que se distraiga la competencia del juez civil, para atraerla en exclusiva al Juez de Violencia sobre la Mujer. De este modo, puede huirse de una sentencia cuyo contenido perjudicial se intuye, 
como señala el mencionado autor, cabe encontrarla en la propia Ley Orgánica del Poder Judicial, cuyo artículo 87 ter, en su apartado cuarto, dispone que «cuando el juez apreciara que los actos puestos en su conocimiento, de forma notoria, no constituyen expresión de violencia de género podrá inadmitir la pretensión, remitiéndola al órgano judicial competente» ${ }^{51}$. En estos casos, por tanto, no conocerá del procedimiento penal y, por ende, tampoco del civil $^{52}$.

Cabría cuestionarse, por último, la conveniencia de mantener la competencia del juzgado de lo civil en aquellos casos en los que, si bien en principio concurren los presupuestos del artículo 87 ter LOPJ para atribuir el conocimiento del proceso civil al juzgado de violencia sobre la mujer, todavía no se ha producido la acumulación de procesos ante este órgano, porque el juzgado civil no se ha inhibido de oficio (supuesto del artículo 49 bis LECiv, apartado primero), ni el juzgado especializado le ha requerido de inhibición (supuesto del artículo 49 bis LECiv apartado tercero) y se produce antes del trasvase inicial del procedimiento civil del órgano civil al penal el sobreseimiento, liberando de responsabilidad al imputado.

\section{Asuntos civiles atribuidos a los juzgados de violencia sobre la mujer}

De acuerdo con lo dispuesto en el artículo 44 de la Ley Orgánica 1/2004, que adiciona el apartado $2 .^{\circ}$ del artículo 87 ter LOPJ, «los Juzgados de Violencia sobre la Mujer podrán conocer en el orden civil, en todo caso de conformidad con los procedimientos y recursos previstos en la Ley de Enjuiciamiento Civil, de los siguientes asuntos:

a) Los de filiación, maternidad y paternidad (cfr. arts. 764 a 768 LECiv). Se trata de los procesos que tienen como objeto la determinación legal de la filiación, así como la impugnación de la que esté legalmente determinada.

en beneficio de otra cuyo contenido - perjudicial o no- es aún desconocido». Ello supone, en definitiva, concluye la mencionada autora, cambio de orden jurisdiccional, de juzgado y de juez. (Escalada LóPEz, María Luisa, Sobre el Juez ordinario..., cit., p. 494).

${ }^{51}$ Vid. en relación con los problemas de aplicación práctica de este precepto, GonZÁLEZ Granda, Piedad, «Los Juzgados de Violencia sobre la mujer en la Ley Orgánica de medidas de protección integral contra la violencia de género» cit., pp. 1634 y 1635.

52 Pone de manifiesto SENÉs Motilla que, «bajo la apariencia formal de una pretendida inadmisión de la pretensión -civil-, lo que subyace es una abstención por falta de uno de los requisitos que la condicionan, a saber, que los hechos perseguidos sean susceptibles de ser calificados como actos de violencia de género». No existe por tanto, tal como pone de manifiesto la autora citada, control de fondo sobre la pretensión civil, sino «apreciación de la incompetencia objetiva por falta de la tipicidad penal requerida». (SENÉs MotILla, Carmen, «La competencia penal y en materia civil de los Juzgados de Violencia sobre la Mujer», cit., pág. 1271). 
b) Los de nulidad de matrimonio, separación y divorcio (cfr. arts. 770 a 777 LECiv).

c) Los que versen sobre relaciones paterno-filiales.

d) Los que tengan por objeto la adopción o modificación de medidas de trascendencia familiar.

e) Los que versen exclusivamente sobre guarda y custodia de hijos e hijas menores o sobre alimentos reclamados por un progenitor contra el otro en nombre de los hijos e hijas menores (cfr. art. 769.3. LECiv).

f) Los que versen sobre la necesidad de asentimiento en la adopción (cfr. art. 781 LECiv).

g) Los que tengan por objeto la oposición a las resoluciones administrativas en materia de protección de menores (cfr. art. 780 LECiv)».

El marco de atribuciones civiles se corresponde, por tanto, con los procesos no dispositivos regulados en el Libro IV de la Ley de Enjuiciamiento Civil, con exclusión de los procesos sobre capacidad de las personas (cfr. arts. 756 a 763 LECiv) y los de reconocimiento de la eficacia civil de resoluciones o decisiones eclesiásticas en materia matrimonial (cfr. art. 778 LECiv $)^{53}$. La atribución del conocimiento de procedimientos con unos principios y tramitación comunes ${ }^{54}$ tiene la ventaja, en palabras de AsENCiO MELLADO ${ }^{55}$, de trasladar a los juzgados de violencia sobre la mujer un régimen procesal determinado en su actuación, uniforme y, por tanto, susceptible de proporcionar cierta seguridad al evitar la aplicación de regímenes procedimentales diversos.

Por otro lado, la letra $d$, referente a procedimientos de trascendencia familiar, no tiene, en cuanto a su denominación, correspondencia con alguno de los procedimientos establecidos en la Ley de Enjuiciamiento Civil. Partiendo de esta constatación, se ha apuntado que debería aplicarse este apartado a los procedimientos relativos a la modificación de las medidas adoptadas en los procedimientos matrimoniales ${ }^{56}$. Asimismo se ha propuesto la inclusión en él de los procedimientos que afectan a parejas de hecho ${ }^{57}$. En este sentido, la

53 En relación con dichas atribuciones vid. UTRERA GuTIÉRREZ, José Luis, «Los procesos de familia en la Ley Integral contra la Violencia de Género. Primera aproximación», Violencia Doméstica, SEPIN, Madrid, 2005, pp. 79-96.

${ }^{54}$ Cfr. arts. 748 a 755 LECiv.

55 Asencio Mellado, José María, «La competencia civil de los Juzgados de Violencia sobre la Mujer», op. cit., p. 75.

${ }^{56}$ Armenteros León, Miguel, «Algunas cuestiones que plantea la competencia de los nuevos Juzgados de Violencia sobre la Mujer», cit., p. 1231; DElgado MARTín, J., «Los Juzgados de Violencia sobre la Mujer», cit., p. 1922.

${ }^{57}$ Castillejo Manzanares, Raquel, «Cuestiones que suscita la Ley Orgánica de Medidas de Protección Integral contra la Violencia de Género», cit., p. 2029; GuTIÉRREZ RoMERO, F. M., «Cuestiones de organización y de competencia en la nueva LO 1/2004, de 
Audiencia Provincial de Barcelona, Sección 12. ${ }^{\text {a }}$, en el Auto de 10 de abril de 2008 (rec. 70/2008), en relación con un supuesto en el que la actora solicita en la demanda la atribución del uso del domicilio familiar, refiriendo la existencia de convivencia con el demandado, durante cuatro años, lo que nos sitúa en el marco jurídico de la Ley de Uniones Estables de Pareja, señala que «ello determina que dicha demanda se incardine en el contenido del art. 87 ter. 2, letra d, de la L.O.P.J, por versar obviamente sobre la adopción de medidas de trascendencia familiar. No puede negarse dicha condición a los integrantes de una unión estable de pareja, no solo por constituir cuestión socialmente aceptada, sino por cuanto la propia L.U.E.P. confiere una regulación análoga a la prevista para las uniones matrimoniales, a lo largo de su articulado, si bien con las peculiaridades y disposiciones propias de la relación y estructura familiar. Por ello la demanda, discrepando esta Sala de lo argumentado por el Juzgado de Violencia sobre la Mujer $n .^{\circ} 3$ de esta ciudad, sí versa sobre materia de la que resultan competentes los Juzgados de Violencia sobre la Mujer, en el orden civil».

Sobre el apartado $e$, señala Delgado MARTíi ${ }^{58}$ que cabe incluir en él los procesos que tengan como finalidad la concreción de los efectos de la ruptura de la pareja de hecho en relación con los hijos menores comunes. Y dentro de este grupo, considera que cabe incluir, con base en una interpretación amplia del término «guarda», tanto aquellos supuestos en los que se ejerciten acumuladamente todas las pretensiones que afectan a los hijos matrimoniales, como, con base en una interpretación amplia del término alimentos, lo relativo al derecho de habitación.

28 de diciembre...», cit., p. 84; Delgado Martín, Joaquín, «Los Juzgados de Violencia sobre la Mujer», cit., p. 1922.

En la Guía Práctica de la Ley Orgánica 1/2004, elaborada por el Observatorio contra la violencia doméstica y de género del Consejo General del Poder Judicial, se señala que «cabe entender que dentro de este apartado se incluyen todos los procedimientos de modificación de medidas. Por otra parte, sería necesario reflexionar sobre si en este apartado cabría incluir aquellos procesos dirigidos por una persona contra quien ha convivido con ella como pareja de hecho sin que existan hijos comunes, con fundamento en una interpretación amplia del término familia: reclamación de pensión compensatoria; indemnización con base en el enriquecimiento injusto, liquidación de los bienes comunes, y la delicada cuestión relativa al uso del domicilio común de la pareja. Esta interpretación parece resultar conforme con la filosofía de la LIVG que tiene como finalidad la protección de la mujer tanto en la pareja matrimonial como en la no matrimonial». (AA.VV., Guía Práctica de la Ley Orgánica 1/2004, de 28 de diciembre, de Medidas de Protección Integral contra la Violencia de Género, CGPJ, Madrid, 2005, p. 62).

${ }^{58}$ Delgado Martín, Joaquín, «Los Juzgados de Violencia sobre la Mujer», cit., p. 1922. 


\section{Conflictos de competencia entre los juzgados civiles y los juzgados de violencia sobre la mujer. Regulación y cuestiones que se suscitan}

\section{Planteamiento}

El artículo 49 bis LECiv, adicionado por la LOMPIVG, tiene como objeto ofrecer una solución a aquellos supuestos en los que puede surgir un conflicto de competencia entre los juzgados de violencia sobre la mujer y los juzgados civiles cuando conocen de una de las materias establecidas en el artículo 87 ter. $2 \mathrm{LOPJ}^{59}$.

No contempla el precepto citado todas las hipótesis en las que puede surgir un conflicto relativo a la determinación de la competencia civil de los juzgados de violencia sobre la mujer en relación con los juzgados de primera instancia. Se ocupa únicamente, de forma coherente con el título que precede a los distintos apartados que lo conforman, de los supuestos en los que se produce la pérdida de competencia de los órganos civiles a favor de los órganos especializados, y es el criterio rector fundamental el de la inhibición de los juzgados del orden jurisdiccional civil a favor de la competencia de los juzgados de violencia sobre la mujer. Por tanto, en el momento en que se den los presupuestos previstos en el artículo 87 ter 2 LOPJ, se producirá la atribución de competencia objetiva para conocer de la demanda civil, la cual podrá ser sobrevenida, en los casos en que la iniciación del proceso penal o emisión de la orden de protección fueran posteriores a la iniciación del proceso civil.

A continuación, se analizarán los distintos supuestos que pueden ser origen de conflictos, atendiendo a si el procedimiento civil por alguna de las materias establecidas en el artículo 87 ter, 2 LOPJ se ha iniciado con anterioridad o posterioridad a la incoación del proceso penal o la emisión de la orden de protección.

2. Procedimiento civil iniciado con anterioridad a la incoación de un proceso penal o a la emisión de una orden de protección. Pérdida de la competencia del juzgado civil

La diferencia fundamental entre este supuesto y el que es objeto de atención en el epígrafe siguiente radica en que, en este caso, la atribución de la competencia objetiva para conocer de la demanda civil del juzgado de vio-

${ }^{59}$ Un estudio de los diferentes tipos de conflictos que pueden suscitarse se puede consultar en AlHambra PÉrez, Pilar, «Cuestiones de competencia, competencia objetiva, subjetiva y funcional», Aspectos procesales y sustantivos de la Ley Orgánica 1/2004, Consejo General del Poder Judicial, Madrid, 2007 (Cuadernos de Derecho Judicial I-2007), págs. 83119. 
lencia sobre la mujer es sobrevenida, ya que, inicialmente, al no concurrir los requisitos del artículo 87 ter $2 \mathrm{LOPJ}$, la competencia para conocer del proceso de familia corresponde al juzgado civil correspondiente (juzgado de primera instancia o juzgado de familia si lo hubiera), sin perjuicio de que, con posterioridad, en caso de cumplirse tales presupuestos, este último deba inhibirse a favor del juzgado de violencia sobre la mujer, que devendría competente.

Por tanto, en estos casos, sí se produce una pérdida de competencia por el órgano inicialmente competente a favor de otro, si bien se mantiene la validez de las actuaciones practicadas hasta ese momento.

\subsection{INHIBICIÓN DE OFICIO DEL JUEZ CIVIL POR INCOACIÓN DEL PROCESO PENAL O EMISIÓN DE ORDEN DE PROTECCIÓN}

\subsubsection{Regulación de la inhibición}

En coherencia con la competencia que, de forma exclusiva y excluyente, corresponde a los juzgados de violencia sobre la mujer cuando concurren los presupuestos del artículo 87 ter LOPJ, el apartado primero del artículo 49 bis LECiv dispone que «cuando un Juez, que esté conociendo en primera instancia de un procedimiento civil ${ }^{60}$, tuviese noticia de la comisión de un acto de violencia de los definidos en el artículo 1 de la Ley Orgánica de Medidas de Protección Integral contra la Violencia de Género, que haya dado lugar a la iniciación de un proceso penal o a una orden de protección, tras verificar la concurrencia de los requisitos previstos en el párrafo tercero del art. 87 ter de la Ley Orgánica del Poder Judicial ${ }^{61}$, deberá inhibirse, remitiendo los autos en el estado en que se hallen al Juez de Violencia sobre la Mujer que resulte competente, salvo que se haya iniciado la fase del juicio oral», con lo que no es, por tanto, de aplicación lo previsto en el artículo 48.3. ${ }^{\circ}$ LECiv $^{62}$.

${ }^{60}$ La referencia al juez que esté conociendo en primera instancia excluye su aplicación a los órganos colegiados que estén conociendo del proceso civil en apelación o casación. Vid. en este sentido, AA.VV., Guía Práctica de la Ley Orgánica 1/2004, de 28 de diciembre, de Medidas de Protección Integral contra la Violencia de Género, CGPJ, Madrid, 2005, p. 84.

${ }^{61}$ Deberá comprobar documentalmente, en original o copia testimoniada, la existencia de una denuncia por juicio de faltas o por delito relativa a actos de violencia de género, siempre en este último caso que esté admitida, o bien mediante una orden de protección. También podría servir para ello la certificación emitida por el Ministerio Fiscal para los supuestos en los que no se ha podido celebrar una comparecencia para adoptar una orden de protección. (ARMENTERos LEÓN, Miguel, «Algunas cuestiones que plantea la competencia de los nuevos Juzgados de Violencia sobre la Mujer», cit., p. 1232). Vid. Instrucción 2/2005 de 2 de marzo de la Fiscalía General del Estado sobre la acreditación por parte del Ministerio Fiscal de los supuestos de Violencia de Género. Esta instrucción, que se puede encontrar en la página <www.fiscal.es $>$, trata sobre el informe que debe emitir el Ministerio Fiscal para el reconocimiento de ciertos derechos (laborales, de seguridad social, funcionariales o sociales) a favor de la víctima al amparo de lo dispuesto en el art. 23 de la L.O. 1/2004. 
Por tanto, el juez civil deberá limitarse a constatar la concurrencia de los presupuestos del artículo 87 ter LOPJ, sin que pueda entrar a valorar la entidad del hecho penal. Constatada dicha concurrencia, no puede negarse a remitir las actuaciones. En cualquier caso, la falta de inhibición cuando fuera procedente puede dar lugar a la nulidad de actuaciones ${ }^{63}$ que puede ser decretada de oficio ${ }^{64}$.

El auto de inhibición deberá emplazarse a las partes para que comparezcan ante el juzgado de violencia sobre la mujer en el plazo de diez días, por aplicación analógica de lo dispuesto en el artículo 65.5. ${ }^{\circ}$ LECiv para la estimación de la declinatoria ${ }^{65}$.

Dicho auto será recurrible en apelación conforme a lo dispuesto en el artículo 66.1 de la Ley de Enjuiciamiento Civil, con efectos suspensivos (art. 456 LECiv). La existencia de este recurso resulta especialmente importante en estos supuestos en los que se priva a las partes de la posibilidad de realizar alegaciones con carácter previo.

La toma de conocimiento puede producirse a instancia de cualquiera de las partes, las cuales deberán aportar testimonio de las actuaciones penales ante el juez civil, sin perjuicio de la posibilidad que tienen de optar por solicitar al juzgado de violencia sobre la mujer que requiera de inhibición al civil, dando lugar a la tramitación señalada en el apartado tercero del artículo 49 bis de la Ley de Enjuiciamiento Civil. En caso de que se inste la inhibición por cualquiera de las partes o por el Ministerio Fiscal en los supuestos en los que interviene en procedimientos civiles en los que alguno de los interesados es menor o incapaz (art. 749 LECiv), si el tribunal rechaza la solicitud, por entender que no concurren los requisitos del artículo 87 ter. 3 LOPJ, dictará un auto contra el que solo cabe recurso de reposición en el plazo de cinco días, que carece de efectos suspensivos, sin perjuicio de alegar de nuevo la falta de competencia objetiva en la apelación contra la sentencia definitiva de que se trate (art. 66 LECiv) ${ }^{66}$.

Por otro lado, abundando en lo relativo a las posibilidades de las partes, en caso de que el órgano jurisdiccional civil no proceda a la remisión de las

${ }^{63}$ Se produce por tanto, en estos casos, una derogación de lo dispuesto en el artículo 9.6 LOPJ que, con carácter general, en relación con la falta de jurisdicción, establece que los órganos judiciales la apreciarán de oficio «y resolverán sobre la misma con audiencia de las partes y del Ministerio Fiscal».

${ }^{63}$ Vid. arts. 48.2 y 225.1 LECiv y 238.1 LOPJ.

${ }^{64}$ Vid. arts. 227.2 LECiv y 240.2 LOPJ.

${ }^{65}$ PÉreZ-Olleros SÁncheZ-Bordona, Francisco Javier, «Cuestiones y respuestas sobre la Ley Orgánica de Medidas de Protección Integral contra la Violencia de Género», cit., pág. 1840.

${ }^{66}$ Pérez-Olleros Sánchez-Bordona, Francisco Javier, «Cuestiones y respuestas sobre la Ley Orgánica de Medidas de Protección Integral contra la Violencia de Género», cit., p. 1840. 
actuaciones, hay que tener en cuenta que no cabe el planteamiento de la declinatoria (art. 49 bis 4 II LECiv), por lo que deberán hacer valer la competencia del juzgado de violencia sobre la mujer presentando ante aquel testimonio del auto de incoación de las diligencias previas o de juicio de faltas, de admisión de querella o de la orden de protección adoptada ${ }^{67}$ por este juzgado especializado, para propiciar así el planteamiento por este del conflicto o cuestión de competencia ${ }^{68}$.

En cuanto al margen de actuación por parte del juzgado de violencia sobre la mujer, si bien no resulta de aplicación lo dispuesto en el apartado cuarto del artículo 49 bis LECiv, en caso de que considere que no concurren los presupuestos del artículo 87 ter LOPJ, podrá inadmitirla ${ }^{69}$. Ni la Ley Orgánica de Violencia de Género, ni la Ley de Enjuiciamiento Civil contemplan, sin embargo, la posibilidad de que el juzgado de violencia sobre la mujer al que se remitan las actuaciones civiles se niegue a aceptarlas. La primera duda que suscita esta posibilidad, a mi juicio incuestionable, es la de ante qué tipo de conflicto estamos y, concretamente, la de si se trata de un «conflicto de competencia» o estamos ante una «cuestión de competencia». A este respecto, cabe recordar que, de acuerdo con lo dispuesto en el artículo 42 LOPJ, los conflictos de competencia son los que surgen en relación con el conocimiento de un asunto determinado «entre Juzgados o Tribunales de distinto orden jurisdiccional, integrados en el Poder Judicial». Es decir, el conflicto que se produce entre órganos judiciales de distintos órdenes jurisdiccionales. Por su parte, estaremos ante una cuestión de competencia cuando la colisión se produzca entre órganos del mismo orden jurisdiccional (arts. 51 y 52 LOPJ). Teniendo en cuenta que los juzgados de violencia sobre la mujer están incardinados en el orden jurisdiccional penal y que el conflicto se plantea respecto de órganos civiles (juzgados de primera instancia espe-

${ }^{67}$ En relación con la orden de protección, señala AsEncio Mellado que «obviamente, solo se acordará la inhibición como consecuencia de la emisión de una orden de protección cuando la dicte el JVM competente, nunca, pues, si es consecuencia de un Juez de instrucción o de uno de Guardia (téngase en cuenta que, si la pronuncia un Juzgado territorialmente incompetente, nunca será el de Violencia sobre la Mujer, salvo que se desconozca el domicilio de la víctima). Ello es así por cuanto el precepto obliga a remitir las actuaciones al JVM competente, así como que las partes están obligadas a aportar, para pedir la inhibición, testimonio procedente el JVM competente. Si la orden de protección es dictada por un Juez incompetente, habrá de esperarse, para aportar el referido testimonio o para la inhibición a que las actuaciones sean asumidas por el JVM competente». (AsENCio Mellado, José María, «La competencia civil de los Juzgados de Violencia sobre la Mujer», op. cit., p. 83).

${ }^{68}$ En este sentido, vid. Muerza EsParZA, Julio, «Aspectos procesales de la LO 1/2004, de 28 de diciembre», op. cit., pp. 62 y 63.

${ }^{69}$ En este sentido, Delgado Martín, Joaquín, «Los Juzgados de Violencia sobre la Mujer», cit., p. 1924. 
cializados o no), habría que concluir que estamos ante un conflicto de competencia $^{70}$.

Sin embargo, fundamentalmente por razones prácticas, teniendo en cuenta que el procedimiento para su resolución es mucho más sencillo ${ }^{71}$, se ha defendido, dado que la naturaleza del objeto del proceso, civil, no es discutida, que podría considerarse como una cuestión de competencia objetiva en el orden jurisdiccional civil (aunque uno de los órganos forme parte del orden jurisdiccional penal) ${ }^{72}$. En este sentido, podría admitirse que el juzgado de violencia sobre la mujer actúa aquí como órgano civil de primera instancia ${ }^{73}$. De aceptarse este planteamiento que es, en la práctica, el que parece seguirse, resolvería el conflicto el superior jerárquico común a ambos órganos, de acuerdo con lo dispuesto en los artículos 51 y $52 \mathrm{LOPJ}^{74}$.

${ }^{70}$ Planchadell Gargallo, Andrea, «La competencia del Juez de Violencia sobre la Mujer», p. 303.

71 Téngase en cuenta que en el caso de darle el tratamiento procesal previsto para los «conflictos de competencia», habría que seguir el procedimiento establecido en los artículos 42 a 50 LOPJ, y corresponde su resolución a una Sala Especial del Tribunal Supremo, conocida como Sala de Conflictos de Competencia, presidida por el presidente y compuesta por dos magistrados, uno por cada orden jurisdiccional en conflicto, que serán designados anualmente por la Sala de Gobierno.

${ }^{72}$ En este sentido, señala MuERZA EsPARZA que «aceptar que nos encontramos, no ante un conflicto de competencia sino ante una cuestión de competencia objetiva en el orden jurisdiccional civil (aunque uno de los órganos forme parte del orden jurisdiccional penal), dado que la naturaleza del objeto del proceso, civil, no es discutida, puede resultar mucho más práctico, siquiera sea porque el procedimiento previsto resulta más sencillo y rápido». (MuERZA Esparza, Julio, «Aspectos procesales de la LO 1/2004, de 28 de diciembre», op. cit., p. 61).

${ }^{73}$ A partir de dicha consideración entiende Cubillo LóPEz que estamos ante una cuestión de competencia negativa. (CuBILlo LóPEZ, Ignacio, «Los Juzgados de Violencia sobre la Mujer y la determinación de su competencia», op. cit., p. 159).

${ }^{74}$ En este sentido, el Auto de la Audiencia Provincial de Murcia, Sección 1. a, de 2 de mayo de 2007, rec. 236/2007, si bien alude indistintamente a cuestión de competencia o conflicto de competencia dice literalmente lo siguiente: «El tema que se somete a la Sala (cuál es el órgano judicial objetivamente competente) tiene un problema previo que resolver, pues no viene regulada la forma de plantear la cuestión de competencia entre los distintos órganos judiciales, quizás porque la nueva regulación parte de la idea de que no es posible, pues siempre ha de prevalecer la decisión del Juzgado de Violencia sobre la Mujer, y no puede plantearse por las partes la declinatoria (art. 49 bis LEC). Pero, como resulta obvio en el presente caso, ello no es así, y son múltiples las hipótesis en que pueden surgir cuestiones de competencia, suscitadas por los propios Juzgados (...). Debe acudirse, en tales supuestos, a las previsiones del artículo 46 de la Ley de Enjuiciamiento Civil, en su remisión a la regulación de las cuestiones de competencia, lo que habrá de determinar la aplicación del artículo 60, sobre conflicto negativo de competencia territorial, lo que permite adoptar un sistema rápido y definitivo para resolver la situación, sin más dilaciones como se pretende en la nueva regulación de la materia sobre todo teniendo en cuenta que esta Sala es la competente para conocer de los recursos derivados en materia matrimonial y en materia de violencia de género». 


\subsubsection{Especial referencia al límite temporal para la inhibición}

Expuesta, en líneas generales, la regulación contenida en el párrafo primero del artículo 49 bis LECiv, hay que detenerse en una de las cuestiones que más dudas interpretativas ha suscitado en la doctrina y en el ámbito judicial, y que no es otra sino la relativa al límite temporal para la inhibición por parte del juez civil.

Efectivamente, la aplicación práctica del apartado primero del citado precepto ha planteado numerosas interpretaciones en torno a la desafortunada expresión concerniente a la referida «fase del juicio oral», ya que un sector doctrinal mayoritario ${ }^{75}$, respaldado por varias resoluciones judiciales ${ }^{76}$, considera que, a pesar de que terminológicamente parece propia del proceso penal, debe interpretarse como referida al proceso civil, lo cual plantea el problema de dilucidar cuándo se entiende, en el ámbito del juicio verbal, que es el adecuado para la tramitación de este tipo de procedimientos ${ }^{77}$, abierta dicha fase, al considerar, con carácter general, que habría que estar al momento en el que se ha dictado providencia y se ha señalado la fecha para

\footnotetext{
${ }^{75}$ SenÉs Motilla, Carmen, «La competencia penal y en materia civil de los Juzgados de Violencia sobre la Mujer», cit., p. 1272; CASTILLEJo MANZANARES, Raquel, «Cuestiones que suscita la Ley Orgánica de medidas de protección integral contra la violencia de género», cit., p. 2029; ONTIVEROS RodRíGUEZ, Francisco, «Competencia civil de los Juzgados de Violencia sobre la Mujer: el art. 49 bis de la Ley de Enjuiciamiento Civil (problemática y propuestas de reforma)», cit., p. 1834; Delgado MARTín, Joaquín, «Los Juzgados de Violencia sobre la Mujer», cit., p. 1926; SÁNCHEZ BARRIOS, Inmaculada, «Comentario al artículo 57», en Sanz Mulas, Nieves; González Bustos, M. Ángeles; Martínez Gallego, Eva M. ${ }^{a}$ (coords.), La Ley de Medidas de Protección Integral contra la Violencia de Género, Iustel, Madrid, 2005, p. 230.

La Guía Práctica de la Ley Orgánica 1/2004, elaborada por el Observatorio contra la violencia doméstica y de género del Consejo General del Poder Judicial, considera igualmente tal expresión referida al proceso civil, entendiendo que cuando el órgano civil hubiere señalado para el juicio o vista ya no cabría inhibición a favor de los juzgados de violencia sobre la mujer. (AA.VV., Guía Práctica de la Ley Orgánica 1/2004, de 28 de diciembre, de Medidas de Protección Integral contra la Violencia de Género, CGPJ, Madrid, 2005, p. 84).

${ }^{76}$ Vid., entre otras, AAP de Vizcaya, Sección 4. a, de 29 de junio de 2006, rec. 409/2006; AAP de Vizcaya, Sección 4. ${ }^{a}$, de 28 de julio de 2006, rec. 425/2006; AAP de Madrid, Sección 22. a, de 31 de julio de 2006, rec. 650/2006; AAP de Badajoz, Sección 3. a, de 24 de abril de 2007, rec. 175/2007; AAP de Murcia, Sección 1. a, de 2 de mayo de 2007, rec. 236/2007; AAAP de Santa Cruz de Tenerife, Sección 1. a, de 10 de diciembre de 2007, rec. 704/2007; 19 de noviembre de 2007, rec. 564/2007; 9 de octubre de 2007, rec. 544/2007; 16 de junio de 2008 , rec. $334 / 2008$.

${ }^{77}$ Dispone el artículo 753 LECiv que «salvo que expresamente se disponga otra cosa, los procesos a que se refiere este Título se sustanciarán por los trámites del juicio verbal, pero de la demanda se dará traslado al Ministerio Fiscal, cuando proceda, y a las demás personas que, conforme a la Ley, deban ser parte en el procedimiento, hayan sido o no demandados, emplazándoles para que la contesten en el plazo de veinte días, conforme a lo establecido en el artículo 405 de la presente Ley».
} 
la vista del procedimiento principal ${ }^{78}$ o para la comparecencia de las medidas provisionales ${ }^{79}$.

En los casos de separación o divorcio instados de mutuo acuerdo o por un cónyuge con el consentimiento del otro, dada la inexistencia de juicio oral en su tramitación, se ha señalado que es a partir de la comparecencia para la ratificación del convenio cuando el juez de lo civil continuará conociendo del proceso hasta el final, sin tener que inhibirse a favor del juzgado de violencia sobre la mujer aunque existan actos de violencia de género ${ }^{80}$. A favor de esta interpretación se esgrimen los siguientes argumentos:

En primer lugar, se alega el propio tenor literal del precepto, y se señala que la redacción del precepto indica que se refiere al proceso civil, ya que, en él, el legislador se está poniendo en todo momento en la posición del juez civil $^{81}$.

${ }^{78}$ Delgado Martín, Joaquín, «Los Juzgados de Violencia sobre la Mujer», cit., p. 1926. En este sentido señala el AAP de Barcelona, Sección 12. ${ }^{a}$, de 25 de julio de 2007, rec. $445 / 2007$, que «la expresión de inicio de la fase de juicio oral debe entenderse referida al procedimiento principal, en el que se sustancia la acción ejercitada y del que el proceso de medidas constituye pretensión coetánea y sometida al ejercicio de dicha acción principal, de forma que no puede existir este si no existe aquel, mientras que podrá sustanciarse procedimiento de divorcio, dada la acción ejercitada en el supuesto de autos, sin pretensión de Medidas Provisionales, por lo que cualquier referencia a una fase procesal deberá serlo para el procedimiento principal. Ello determina que el juicio o vista civil a la que se refiere el art. 49 bis de la LEC, sea el juicio o vista del procedimiento principal, que es el que convoca a las partes a la celebración de vista, de conformidad con lo previsto en el art. 770 de la LEC». Vid. igualmente AAP de Badajoz, Sección 3. , de 24 de abril de 2007, rec. 175/2007; AAP de Vizcaya, Sección 4. ${ }^{\text {a }}$, de 25 de enero de 2007, rec. 686/2006; AAP de Vizcaya, Sección 4. ${ }^{\text {a }}$, de 28 de julio de 2006, rec. 425/2006; AAP de Barcelona, Sección 12.a , de 1 de marzo de 2006, rec. 999/2005.

Para Gutiérrez Romero, la fase del juicio oral se entiende iniciada cuando el procedimiento haya llegado a la celebración de vista y, por ende, el juez haya de dictar sentencia (art. 443 LECiv). En los procedimientos de separación o divorcio de mutuo acuerdo, ese límite lo considera referido a la comparecencia para la ratificación del convenio. (GUTIÉRREZ RoMERo, F. M., «Cuestiones de organización y de competencia en la nueva LO 1/2004, de 28 de diciembre...», cit., p. 95).

${ }^{79}$ Delgado Martín, Joaquín, «Los Juzgados de Violencia sobre la Mujer», cit., p. 1926. Vid. AAP de Vizcaya, Sección 4. a , de 18 de julio de 2006, rec. 408/2006 (FJ 2. ${ }^{\circ}$ ); AAP de Vizcaya, Sección 4. a , de 29 de junio de 2006, rec. 409/2006; AAP de Girona, Sección 2. de 1 de octubre de 2007, rec. 461/2007.

${ }^{80}$ Vid. AAP de Madrid, Sección 22. a, de 31 de julio de 2006, rec. 650/2006 (FJ 1. ${ }^{\circ}$ ); AAAP de Alicante, Sección 5. a, de 31 de mayo de 2006, rec. 220/2006 y 7 de junio de 2006, rec. 270/2006.

${ }^{81}$ Armenteros León pone de manifiesto a este respecto que se trata de un artículo que forma parte de la Ley de Enjuiciamiento Civil. (ARMENTERos León, Miguel, «Algunas cuestiones que plantea la competencia de los nuevos Juzgados de Violencia sobre la Mujer», cit., p. 1232). 
En segundo lugar, que la inhibición tras la fase del juicio oral civil, conduciría a un grave menoscabo de los principios de oralidad, publicidad, inmediación y concentración ${ }^{82}$.

En tercer lugar, ahondando en esta línea, se alega la necesaria observancia escrupulosa de los principios inherentes e informadores del ordenamiento jurídico, entre los que, en materia como la que nos ocupa, cobran especial significación las razones de economía procesal, en evitación de reprochables dilaciones y actuaciones procesales itinerantes de los litigantes, que mal se compaginan con la tutela judicial efectiva ${ }^{83}$.

Frente a esta tesis, otros autores ${ }^{84}$, también en este caso con su correspondiente respaldo jurisprudencial ${ }^{85}$, consideran que la expresión «fase del juicio oral» debe entenderse referida al proceso penal, utilizando los siguientes argumentos:

Por un lado, se alega que, técnicamente, «juicio oral» solo existe en los procesos penales, y se señala que en el caso de los juicios civiles verbales, las actuaciones orales se concentran en un acto que se denomina «vista» (art. 443 LECiv) $)^{86}$.

Por otro lado, se esgrime que el límite de que todavía no se haya iniciado la fase del juicio oral, referida al proceso penal, tiene el sentido cabal de que las actuaciones aún se mantienen en manos del juzgado de violencia sobre la mujer en cuanto órgano instructor. Es decir, señala CUBILLO LÓPEZ,

${ }^{82}$ Vid. AAP de Vizcaya, Sección 4. ${ }^{\text {a }}$, de 28 de julio de 2006, rec. 425/2006 (FJ 2. ${ }^{\circ}$ ).

${ }^{83}$ Para GutiérRez ROMERo «aunque la redacción es confusa, una interpretación integradora de los apartados del artículo 49 bis LEC nos lleva a concluir que se está refiriendo al Juicio Civil y tiene su explicación en la finalidad de no paralizar y evitar "peloteos" entre el Juez Civil y el Juez de violencia». (GuTIÉRrez Romero, F. M., «Cuestiones de organización y de competencia en la nueva LO 1/2004, de 28 de diciembre...», cit., p. 95).

${ }^{84}$ MuERZA EsPARZA considera que «lo más oportuno, para determinar la inhibición o no del Juez de Primera Instancia, es estar al momento en que el órgano jurisdiccional penal previsto por la ley haya decretado la apertura del juicio oral, puesto que es el momento en que el objeto del proceso penal ha quedado delimitado, aunque no sea definitivamente». (MUERZA EsPARZA, Julio, «Aspectos procesales de la LO 1/2004, de 28 de diciembre», op. cit., pp. 63 y 64).

${ }^{85}$ Defienden, entre otras, que la referencia debe entenderse hecha al procedimiento penal, reiterando el criterio mantenido en resoluciones anteriores los Autos de la Audiencia Provincial de Tarragona, Sección 1. a, de 26 de noviembre de 2007, rec. 483/2007; de 28 de noviembre de 2007, rec. 486/2007 y de 31 de marzo de 2008, rec. 627/2007; el Auto de la Audiencia Provincial de Cantabria, Sección 2. a, de 26 de julio de 2007, rec. 20/2007; los Autos de la Audiencia Provincial de Madrid, Sección 22. a, de 8 de marzo de 2006, rec. 3/2006 y 10 de julio de 2006, rec. 578/2006; los Autos de la Audiencia Provincial de Madrid, Sección 24. ${ }^{\text {, }}$, de 14 de febrero de 2007, rec. 73/2007, 10 de abril de 2008, rec. 27/2008 y de 21 de mayo de 2008, rec. 1155/2007.

${ }^{86}$ Cubillo LóPez, Ignacio, «Los Juzgados de Violencia sobre la Mujer y la determinación de su competencia», op. cit., p. 155. 
«está indicando que, una vez finalizada la fase de instrucción y elevada la causa al órgano encargado del enjuiciamiento, ha perdido su razón de ser -y de hecho no resulta ya posible- la tramitación, por un mismo órgano, del proceso civil y del proceso penal (en su fase de instrucción)» ${ }^{87}$.

En este sentido, AsENCIO MELlado ${ }^{88}$ señala que la acumulación de las pretensiones civil y penal se da en estos supuestos ante el mismo juzgado, que no es otro que el juzgado de violencia sobre la mujer, añadiendo que, cuando en el apartado tercero del artículo 49 bis LEC se regula el requerimiento de inhibición por parte el juez penal, únicamente se hace referencia al juzgado de violencia sobre la mujer, sin contemplar la posibilidad de requerimiento de las actuaciones al juez civil, cuando el proceso penal está ya tramitándose ante el juzgado de lo penal o la audiencia provincial. Acogiendo este planteamiento, la Audiencia Provincial de Madrid, Sección 24. ${ }^{\text {, }}$, en el Auto de 27 de febrero de 2008 (rec. 112/2008) advierte a estos efectos, «que el artículo 87 ter de la LOPJ, a los fines de la integración obligada de los procedimientos penales y civiles en el Juzgado de Violencia sobre la Mujer, requiere que se hayan "iniciado" ante el mismo actuaciones penales, o se haya adoptado una orden de protección, pero sin hacer mención alguna a ulteriores fases del procedimiento penal, idea en la que insiste el apartado c) de tal precepto, en el que se habla de imputado, pero nunca de acusado, procesado y, mucho menos, de condenado».

En la misma línea, el artículo 49 bis de la LECiv hace referencia en su apartado n. ${ }^{\circ} 1$ a la «iniciación de un proceso penal» o a la adopción de «una orden de protección», guardando significativo silencio respecto de ulteriores fases del procedimiento penal, lo que se reitera en su apartado n..$^{\circ} 2 \mathrm{y}$, especialmente, en el n. ${ }^{\circ} 3$, que exige que el juzgado de violencia sobre la mujer «esté conociendo de una causa penal por violencia de género» (y no que haya conocido), y ello en orden a poder requerir de inhibición al juzgado civil que esté tramitando un proceso civil de los comprendidos en el artículo 87 ter de la LOPJ. Se añade, de igual manera significativa, que al correspondiente requerimiento deberá acompañarse testimonio de la «incoación de diligencias previas o de juicio de faltas, del auto de admisión de la querella, o de la orden de protección adoptada», en inequívoca referencia a fases iniciales del procedimiento penal, sin ampliarla a aquellas otras en las que, tras la apertura del juicio oral, el juzgado de violencia sobre la mujer pierde su competencia para seguir tramitando las actuaciones penales, pues, en otro caso, no se cumpliría el requisito del conocimiento actual ("esté conociendo")».

${ }^{87}$ Cubillo López, Ignacio, «Los Juzgados de Violencia sobre la Mujer y la determinación de su competencia», op. cit., p. 155.

${ }^{88}$ Asencio Mellado, José María, «La competencia civil de los Juzgados de Violencia sobre la Mujer», op. cit., p. 85. 
En efecto, concluye la citada resolución, «conforme a la nueva normativa, el Juzgado de Violencia sobre la Mujer, a salvo de los juicios de faltas, queda configurado como un órgano de instrucción, que no de enjuiciamiento, de modo tal que, una vez abierto el juicio oral, no tiene ya a su disposición las actuaciones penales. Por ello, y aunque la finalidad perseguida por la Ley es la de otorgar una protección integral a la víctima de actos de violencia de género, mediante la asignación a un solo Juzgado de todos los procedimientos que afecte a aquella, tal objetivo no puede cumplirse cuando, al tiempo de iniciarse el procedimiento civil, las actuaciones penales han salido ya de la esfera de actuación del Juzgado de Violencia sobre la Mujer».

Por todas las razones expuestas, desde esta perspectiva, se interpreta que la expresión relativa a la fase del juicio oral debe entenderse referida al proceso penal, ya que no se encuentra mencionada en ningún otro lugar de la LECiv, y encuentra, por el contrario, su natural acomodo y continua regulación en la Ley de Enjuiciamiento Criminal, con innumerables menciones de dicho concepto técnico-jurídico, en referencia, además, no a un acto concreto, como en el procedimiento civil puede ser el juicio verbal o la vista, sino a toda una fase procedimental, que se inicia con la apertura del juicio oral y culmina con su celebración ${ }^{89}$.

Este planteamiento no puede llevar a olvidar la necesaria protección de los principios procesales y constitucionales que esgrimen los defensores de la tesis que vinculan la referencia a la «fase del juicio oral» al proceso civil. Por ello, se ha tratado de buscar, tanto desde la doctrina, como en el ámbito judicial, una solución lógica que huye de la posibilidad de que el procedimiento civil del que pueda estar conociendo el juzgado de familia o el de primera instancia no especializado quede a expensas de su remisión en cualquier momento al juzgado de violencia sobre la mujer. A estos efectos, se señala como límite temporal en relación con el proceso civil el de la citación a las partes a juicio verbal o vista ${ }^{90}$, es decir, el mismo que esgrimen la mayoría de los defensores de la tesis contraria. Sin embargo, para los partidarios de esta posición, esta solución no habría de discurrir por la tergiversación de una terminología técnica tan clara como la recogida en la Ley («fase del jui-

\footnotetext{
${ }^{89}$ En este sentido, PÉrez-Olleros SÁnchez Bordona entiende que la fase del juicio oral se refiere al procedimiento penal, "pues en el procedimiento de familia no se distingue en la dogmática una fase de juicio oral, a diferencia de en el procedimiento penal, que es la fase que sigue a la intermedia o preparatoria del juicio oral, que se inicia con el auto de apertura de juicio oral en procedimientos por delito o con el inicio del juicio en el juicio de faltas». Pérez-Olleros Sánchez Bordona, Francisco Javier, «Cuestiones y respuestas sobre la Ley Orgánica de Medidas de Protección Integral contra la Violencia de Género», cit., p. 1839.

${ }^{90}$ En este sentido, dice el referido Auto de la Audiencia Provincial de Madrid, Sección 24. a , de 27 de febrero de 2008, rec. 112/2008 que la solución lógica «... habría de llevar a perpetuar la jurisdicción en el supuesto de que ya se hubiesen sobrepasado los iniciales trámites de alegación por escrito, y citado a las partes a juicio verbal o vista».
} 
cio oral»), sin encaje posible en la normativa civil, sino que puede defenderse con base en la aplicación de la normativa relativa a la acumulación de procesos civiles $^{91}$, ya que el artículo 77 de la LECiv, en su apartado cuarto, establece expresamente que «para que sea admisible la acumulación de procesos será preciso que estos se encuentren en primera instancia, y que en ninguno de ellos haya finalizado el juicio a que se refiere el artículo 433 de esta Ley» y todo ello, siempre, sin perder de vista la protección imprescindible de los principios de oralidad, publicidad, inmediación, concentración y economía procesal, también expresamente regulados en la Ley de Enjuiciamiento Civil.

En mi opinión, y sin desconocer la solidez de ciertos argumentos esgrimidos por la tesis que considera que la referencia debe entenderse realizada al proceso penal, es más correcta la contraria ${ }^{92}$.

En este sentido, comenzando por el argumento gramatical, hay que tener en cuenta que la referencia a la fase del juicio oral se emplea y circunscribe en un párrafo que empieza estableciendo que «cuando un Juez de primera instancia que esté conociendo de un procedimiento civil», lo que sitúa el conocimiento de la existencia o no de aquella fase precisamente en el juzgador de primera instancia, que es el sujeto de la actuación jurisdiccional que se describe en el precepto señalado. Es el juez civil quien podrá determinar la fase en la que se encuentra el procedimiento civil, no alcanzando su conocimiento al procedimiento penal que se encuentra en otro juzgado.

Por otro lado, si bien el artículo 87 ter LOPJ, a los fines de integración de los procedimientos penales y civiles en el juzgado de violencia sobre la mujer, requiere que se hayan iniciado ante este actuaciones penales o se haya adoptado una orden de protección, dicha solución legal parece obedecer a que tales actuaciones penales han tenido, por fuerza, que haberse iniciado, puesto que, de no ser así, no nace el supuesto fáctico susceptible de dicha regulación legal. Hay que poner de manifiesto, además, que no obstante la conclusión de la instrucción por el juzgado de violencia sobre la mujer, este recibirá la sentencia recaída, en el procedimiento penal, según establece el

\footnotetext{
${ }^{91}$ Asencio Mellado, José María, «La competencia civil de los Juzgados de Violencia sobre la Mujer», op. cit., p. 85.

${ }^{92}$ Vid. los argumentos recogidos en el texto en el Voto Particular al Auto de la Audiencia Provincial de Madrid, Sección 22. a, de 30 de julio de 2008, rec. 813/2008. A los argumentos expuestos añade que «quedan, en fin, también, sin explicación lógica -aceptando la inviabilidad del conocimiento de estos asuntos por el Juzgado de Violencia sobre la Mujer una vez iniciada la fase del Juicio Oral, en la interpretación terminológica de esta expresión jurídico-procesal utilizada hasta ahora exclusivamente en la regulación del procedimiento penal-, la existencia de la llamada fase de juicio oral en las también reguladas por el legislador faltas u "órdenes de protección", procedimientos y medidas a tramitar y adoptar, en su caso por el Juzgado de Violencia sobre la Mujer, que en su estructura, naturaleza y condición carecen ni como fase ni como actos propios, individuales o independientes de la llamada "fase de juicio oral"».
} 
artículo 160 LECrim, y se le dirigirá la comunicación con el testimonio de la sentencia dictada por el juzgado de lo penal, cuando a este le hubiera correspondido el enjuiciamiento de los hechos, según modifica el artículo 55 de la Ley Orgánica 1/2004, de lo que se infiere que en el juzgado de violencia sobre la mujer permanecen las actuaciones civiles, para la continuación de su tramitación.

A todo lo expuesto cabe añadir que el designio primordial y básico del legislador al crear estos juzgados especializados es que en un mismo juzgado se sigan y tramiten los procesos penales y civiles, para que un mismo juez decida los aspectos penales y civiles de una crisis matrimonial donde haya existido un acto de violencia de género.

En conclusión, cabe entender que el artículo 87 ter LOPJ no pone límites temporales para que el juzgado de violencia sobre la mujer asuma esta competencia civil en función de la fase en que se halle el proceso penal, al entender que el artículo 49 bis LECiv se refiere a una inhibición que debe acordar el órgano jurisdiccional civil con una excepción que se vincula más bien al procedimiento civil, y que, en definitiva, trata de evitar que un acto de juicio verbal ya iniciado tenga que repetirse ante otro juzgado, retrasando, además la decisión pronta y definitiva, que es lo que en estos casos de violencia de género interesa fundamentalmente.

Esta es, por otro lado, la tesis por la que ha optado el Tribunal Supremo, Sala Primera, entre otros, en el Auto de 24 de septiembre de 2008, rec. 91/2008, acogiendo el criterio del Ministerio Fiscal, que es, por otro lado, el seguido en la Circular de la Fiscalía General del Estado 4/05, de 18 de julio de 2005, según la cual, debe considerarse iniciada la fase del juicio oral cuando se haya llegado a la vista del artículo 443 de la Ley de Enjuiciamiento Civil.

En cualquier caso, lo expuesto hasta el momento, pone de manifiesto que existen argumentos, a mi juicio suficientemente sólidos, para mantener una y otra posición. Por ello, y dada la inseguridad jurídica que la división jurisprudencial existente puede generar, resultaría conveniente una reforma legislativa que aclare definitivamente la cuestión. Todo ello, y sin perjuicio de que sea posible encontrar una solución que resulte respetuosa con el tenor literal de la normativa actual, evite disfunciones en la aplicación de los distintos apartados del artículo 49 bis, y respete los principios esenciales del proceso civil.

\subsection{REQUERIMIENTO DE INHIBICIÓN}

Cuando un juez de violencia sobre la mujer que esté conociendo de una causa penal por violencia de género tenga conocimiento de la existencia de un proceso civil, y verifique la concurrencia de los presupuestos establecidos en el apartado tercero del artículo 87 ter de la LOPJ, requerirá de inhibición al tribunal civil, el cual deberá acordar de inmediato su inhibición y la remisión de los autos al órgano requirente. 
Pese al silencio legal, una interpretación sistemática del artículo 87 ter LOPJ y del artículo 49 bis LECiv permite entender que el requerimiento de inhibición procederá igualmente en los supuestos en los que no se haya incoado la causa penal, pero se haya adoptado una orden de protección ${ }^{93}$.

El requerimiento deberá acompañarse de testimonio de la incoación de diligencias previas o de juicios de faltas, de auto de admisión de la querella o de la orden de protección adoptada (art. 49 bis. 3 LECiv).

A diferencia de lo que ocurre en el analizado con anterioridad, en este caso no se establece expresamente un límite temporal para el requerimiento de inhibición al juzgado de primera instancia. En relación con el proceso penal podría interpretarse que dicha indicación es innecesaria puesto que se parte de que las actuaciones están a disposición del juzgado de violencia sobre la mujer, por cuanto es este órgano el que lleva a cabo el requerimiento y, por tanto, no se habrá iniciado la fase del juicio oral del procedimiento penal. Cabe cuestionarse si, en cuanto al proceso civil que está tramitándose, existe un momento preclusivo para la inhibición. En mi opinión, será de aplicación también a este respecto la interpretación mantenida en relación con el apartado primero del artículo 49 bis de la Ley de Enjuiciamiento Civil ${ }^{94}$.

En cualquier caso, para evitar cualquier duda al respecto también en relación con este precepto considero que debería abordarse la reforma de dicho apartado para establecer el mismo límite temporal a todos los supuestos en los que se produce la pérdida de la competencia del juzgado de primera instancia a favor del juzgado de violencia sobre la mujer.

\subsection{SUPUESTO PREVISTO EN EL APARTADO SEGUNDO DEL ARTíCULO 49 BIS DE LA Ley de EnJuiciamiento Civil}

Prevé el artículo 49 bis, en su apartado segundo, que cuando el juez que esté conociendo de un procedimiento civil tuviese noticia de la posible comisión de un acto de violencia de género, que no haya dado lugar a la iniciación de un proceso penal, ni a dictar una orden de protección, tras verificar que concurren los requisitos del párrafo tercero del artículo 87 ter LOPJ, deberá inmediatamente citar a las partes a una comparecencia con el Ministerio Fiscal que se celebrará en las siguientes 24 horas a fin de que este tome conocimiento de cuantos datos sean relevantes sobre los hechos acaecidos. Tras ella, el fiscal, de manera inmediata, habrá de decidir si procede, en las

${ }^{93}$ Así lo entiende también Asencio Mellado, José María, «La competencia civil de los Juzgados de Violencia sobre la Mujer», op. cit., p. 90.

${ }^{94}$ En contra de esta opinión, sin perjuicio de criticarlo, CASTILLEJo MANZANARES considera que el requerimiento de inhibición del juez de violencia no tiene límite. (CASTILlejo ManZanares, Raquel, «Cuestiones que suscita la Ley Orgánica de Medidas de Protección Integral contra la Violencia de Género», cit., p. 2029). 
24 horas siguientes, a denunciar los actos de violencia de género o a solicitar orden de protección ante el juzgado de violencia sobre la mujer que resulte competente.

En el supuesto de que se interponga denuncia o se solicite la orden de protección, el fiscal habrá de entregar copia de la denuncia o solicitud en el tribunal (cabe entender que se refiere al que está conociendo del procedimiento civil), el cual continuará conociendo del asunto hasta que sea, en su caso, requerido de inhibición por el juez de violencia sobre la mujer competente (art. 49 bis. 2 LECiv).

\section{Procedimiento penal u orden de protección anterior a la interposición de la demanda civil}

Se examinará a continuación cuál ha de ser la respuesta del órgano civil (juzgado de primera instancia o, en su caso, juzgado de familia) ante la presentación de la demanda civil que tenga por objeto alguna de las materias enumeradas en el artículo 87 ter LOPJ en caso de que se haya incoado un procedimiento penal ante el juzgado de violencia sobre la mujer o emitido una orden de protección, y, a su vez, en este segundo supuesto, habrá que distinguir en función de que dicho procedimiento penal esté aún tramitándose o haya finalizado por sentencia o auto de sobreseimiento.

\subsection{SuPUeSTO EN EL QUE EL PROCEDIMIENTO PENAL ESTÁ TRAMITÁNDOSE}

En este caso, hay que partir de la competencia inicial, exclusiva y excluyente que, con carácter imperativo corresponde a los juzgados de violencia sobre la mujer para conocer de la demanda civil en estos casos. En consecuencia, todas las actuaciones que, en su caso, se hubieran practicado o se practicaran ante el juez civil serían nulas de pleno derecho por falta de competencia objetiva, por aplicación de lo dispuesto en el artículo 238.1. ${ }^{\circ} \mathrm{LOPJ}$. No se trata, en definitiva, a diferencia del supuesto analizado en el epígrafe anterior, de un caso de pérdida de competencia sobrevenida, sino de una falta de competencia inicial. Entraría en juego la exigencia del control de oficio de la competencia objetiva por parte del juez, previa audiencia de las partes y del Ministerio Fiscal, de acuerdo con lo dispuesto en el artículo 48.3. ${ }^{\circ}$ de la Ley de Enjuiciamiento Civil ${ }^{95}$.

Una vez declarada la falta de competencia, carece de sentido en estos supuestos remitir al juzgado de violencia sobre la mujer actuaciones nulas de

${ }^{95}$ Dispone el artículo 240.2. ${ }^{\circ}$ LOPJ que «... el juzgado o tribunal podrá, de oficio o a instancia de parte, antes de que hubiere recaído resolución que ponga fin al proceso, y siempre que no proceda la subsanación, declarar, previa audiencia de las partes, la nulidad de todas las actuaciones o de alguna en particular». 
pleno derecho, por lo que, de acuerdo con lo dispuesto en el artículo 48 LECiv, quedará a salvo el derecho de las partes de acudir ante el tribunal competente.

Al margen del control de oficio, el carácter imperativo de las normas de competencia objetiva permite que su falta sea alegada por las partes mediante la interposición de la declinatoria.

\subsection{PROCEDIMIENTO PENAL FINALIZAdO POR SENTENCIA ABSOLUTORIA O AUTO DE SOBRESEIMIENTO}

En este caso, considero que será competente para conocer del proceso de familia el juzgado civil, al no concurrir uno de los requisitos exigidos por el artículo 87 ter LOPJ $^{96}$, si bien en el caso del auto de sobreseimiento provi-

${ }^{96}$ Señala ONTIVEROS RODRÍGUEZ que «en estos supuestos parece clara la exigencia de que
la referida resolución judicial que pone fin al proceso penal sea firme pues lo contrario
podría generar un continuo baile de procedimientos entre el JVSM y el Juzgado de Prime-
ra Instancia con el consiguiente perjuicio para la víctima, frustrándose así el objetivo pre-
tendido por la LOMPIVG, que conforme a su Exposición de Motivos, apartado relativo a la
tutela judicial, no es otro que garantizar un tratamiento adecuado y eficaz (...) a las vícti-
mas de la violencia de género y ello a través de medidas procesales que permitan procedi-
mientos ágiles y sumarios». (ONTIVEROS RoDRíGUEZ, Francisco, «Competencia civil de los
Juzgados de Violencia sobre la Mujer: el art. 49 bis de la Ley de Enjuiciamiento Civil (problemática y propuestas de reforma)», cit., p. 1836, nota al pie de página núm. 5).

El criterio mantenido por las Audiencias Provinciales es el de excluir la competencia de los juzgados de violencia sobre la mujer para conocer de la causa civil cuando ha recaído sentencia absolutoria o auto de sobreseimiento, por no concurrir en tales casos el requisito del apartado $3 \mathrm{c}$ del artículo 87 ter LOPJ. En este sentido se puede consultar, entre otros, el Auto de 23 de mayo de 2003, de la AP de Murcia, Sección 5. a, rec. 210/2006, en el que siguiendo el criterio mantenido por otras Audiencias, da la razón al Magistrado-Juez del Juzgado de Instrucción, con funciones compartidas de Juzgado de Violencia Sobre la Mujer, tomando como referencia la exposición de motivos de la Ley Orgánica 1/2004, de 28 de diciembre, de Medidas de Protección Integral contra la Violencia de Género y los criterios

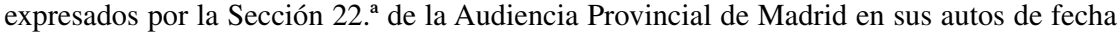
3 de octubre de 2005, rec. 711/2005 y 6 de marzo de 2006, rec. 161/2006. En este sentido, señala que «se ha de coincidir con este último auto en "que, de conformidad con la normativa citada, el procedimiento civil, en supuestos como el que nos ocupa, no puede, en tal aspecto competencial, quedar supeditado a la suerte final de la causa seguida en el orden penal y sí, por el contrario, al estado que esta última mantenga al tiempo de presentarse la demanda"; y también se ha de coincidir con el primero de esos autos en que el artículo 87 ter "no hace referencia alguna al resultado final del procedimiento penal, y sí tan sólo a la iniciación del mismo, lo que se completa con el artículo 49 bis de la Ley de Enjuiciamiento Civil, que dispone que el Juez que esté conociendo de un procedimiento civil y tenga noticias de la comisión de un acto de violencia que haya dado lugar a la iniciación de un proceso penal o a una orden de protección, tras verificar la concurrencia de los requisitos previstos en el estudiado precepto de la Ley Orgánica del Poder Judicial, deberá inhibirse, remitiendo los autos, en el estado en que se hallen, al Juez de Violencia sobre la Mujer que resulte competente, salvo que se haya iniciado la fase de juicio oral"». Pero en este caso, 
sional la cuestión puede ser más dudosa. La solución apuntada por la Fiscalía General del Estado es la de distinguir en función de cuál haya sido la causa del sobreseimiento; si este se ha acordado por no haberse acreditado suficientemente el hecho o por no existir motivos bastantes para dirigir la acusación contra persona determinada, no cabría la inhibición del juez civil a favor del juez penal; en caso de que se trate de un sobreseimiento acordado porque el denunciado no ha podido ser citado o se encuentra en rebeldía, sí procedería la inhibición ${ }^{97}$.

\subsection{PROCEDIMIENTO PENAL FINALIZADO POR SENTENCIA CONDENATORIA}

Algunos autores consideran que, en estos casos, cabría defender la competencia del juzgado de violencia sobre la mujer para conocer del proceso civil que se inicie, al menos hasta el momento en que se produzca la extinción de la responsabilidad penal del sujeto condenado ${ }^{98}$. En este sentido, señala ARMENTEROS LEÓN ${ }^{99}$ que habrá que estar al momento de archivo definitivo de la correspondiente ejecutoria, es decir, al del cumplimiento íntegro

como apunta el referido auto de fecha 12 de mayo de 2006, sobreseído, no existía procedimiento penal al tiempo de la interposición de la demanda, por lo que en ese momento faltaban los condicionantes determinantes de la competencia civil del Juzgado de Violencia».

En el mismo sentido, para un supuesto en el que la sentencia absolutoria estaba recurrida, se pronuncian el Auto de la Audiencia Provincial de Vizcaya, Sección 4. a, de 26 de enero de 2007, rec. 782/2006 y el Auto de la Audiencia Provincial de Alicante, Sección 5. ${ }^{\text {, }}$, de 9 de julio de 2008, rec. 392/2008, que acoge la tesis inhibitoria del juzgado de violencia sobre la mujer, al haber recaído sentencia absolutoria en vía penal, entendiendo que los hechos ya no constituyen expresión de violencia de género, «debiendo tenerse en cuenta que la situación que se decide no es irreversible, como se destaca en la resolución del Juzgado de Violencia sobre la Mujer de Alicante, pues en el supuesto de que la sentencia absolutoria fuese revocada en apelación el Juzgado civil siempre podría derivar la causa hacia el especial de violencia, lo que no ocurriría en caso contrario de asumir este la competencia y ser confirmada la sentencia penal, teniendo obligación de continuar con un procedimiento civil que no le corresponde según el espíritu y finalidad de la Ley». Vid. también el Auto de la Audiencia Provincial de Valladolid, Sección 1. ${ }^{a}$, de 21 de febrero de 2007, rec. 56/2007.

${ }^{97}$ Armenteros León, Miguel, «Algunas cuestiones que plantea la competencia de los nuevos Juzgados de Violencia sobre la Mujer», cit., p. 1233.

98 Ontiveros Rodríguez, Francisco, «Competencia civil de los Juzgados de Violencia sobre la Mujer: el art. 49 bis de la Ley de Enjuiciamiento Civil (problemática y propuestas de reforma)», cit., p 1833; GutiéRrez RoMERo, F. M., «Cuestiones de organización y de competencia en la nueva LO 1/2004, de 28 de diciembre...», cit., p. 95. Este es, igualmente el criterio mantenido en la Guía Práctica de la Ley Orgánica 1/2004, elaborada por el Observatorio contra la violencia doméstica y de género del Consejo General del Poder Judicial (AA.VV., Guía Práctica de la Ley Orgánica 1/2004, de 28 de diciembre, de Medidas de Protección Integral contra la Violencia de Género, CGPJ, Madrid, 2005, p. 64).

${ }^{99}$ Armenteros León, Miguel, «Algunas cuestiones que plantea la competencia de los nuevos Juzgados de Violencia sobre la Mujer», cit., p. 1233. Si fueran varias las penas impuestas, señala este autor, habrá que esperar al cumplimiento de todas ellas. 
de las penas o de remisión definitiva de la pena suspendida, sin necesidad de esperar a la cancelación de antecedentes.

En mi opinión, por el contrario, la competencia corresponderá a los juzgados civiles. En este sentido, coincido con la apreciación de que la voluntad del legislador no ha sido la de atribuir la competencia a los juzgados sobre la mujer para conocer de las cuestiones civiles establecidas en el artículo 87 ter 2 de la LOPJ, siempre que haya existido un hecho penal de su competencia, con independencia de que el proceso penal haya concluido o esté en trámite, pues las reglas reguladoras de conflictos rigen para supuestos de concurrencia de procedimientos y no para los supuestos en los que esa concurrencia no se produce.

No puede obviarse que el artículo 44 de la LO 1/2004 fija la competencia de los juzgados de violencia sobre la mujer para conocer de las causas civiles en atención a que alguna de las partes del proceso civil sea imputado como autor, inductor o cooperador necesario en la realización de actos de violencia de género, lo que evidencia que esa competencia se extiende únicamente a aquellos supuestos de concurrencia de los procedimientos, mientras el proceso penal no haya concluido con absolución o condena del imputado $^{100}$.

Para concluir, y siendo este último argumento aplicable a todos los supuestos en los que el proceso penal ya hubiera finalizado, cabe añadir que si la simple interposición de una denuncia por un delito o falta de violencia de género determinara y perpetuara la jurisdicción tanto penal como civil del juzgado de violencia sobre la mujer, caeríamos en el absurdo de dejar al arbitrio de la parte demandante la determinación de dicha competencia que desde el punto de vista penal es improrrogable y no está sujeta a sumisiones voluntarias $^{101}$.

${ }^{100}$ Vid. en este sentido los Autos de la Audiencia Provincial de Tarragona, Sección 1. a, de 31 de marzo de 2008, rec. 627/2007 y de 26 de noviembre de 2007, rec. 483/2007.

${ }^{101}$ Así se pone de manifiesto en el Auto de la Audiencia Provincial de Salamanca de 27 de junio de 2007 (rec. 240/2007), que señala, en la línea de lo expuesto en el texto, para un supuesto en el que al tiempo de presentarse la demanda civil el procedimiento se encontraba ya sobreseído por medio de resolución firme que «no concurren en el supuesto de autos los requisitos del art. 87. ter 3 LOPJ, ya que no había proceso penal de violencia sobre la mujer al tiempo de presentarse la demanda civil, que por ello no supuso la perpetuación de ninguna jurisdicción de esa naturaleza para el juzgado penal, cuya excepcional competencia en tal materia que le es extraña se apoya únicamente en la previa iniciación y vigencia de las actuaciones penales por delito o falta de violencia sobre la mujer». 
4. Supuesto de interposición de dos demandas civiles en un juzgado civil y en un juzgado de violencia sobre la mujer

Plantea ONTIVEROS RODRÍGUEZ ${ }^{102}$ el supuesto, no contemplado expresamente en la Ley de Enjuiciamiento Civil, de que existan dos demandas que han dado lugar a dos procedimientos distintos ante juzgados diferentes (un juzgado civil y uno de violencia sobre la mujer), cuestionándose cómo habría de llevarse a cabo la acumulación de ambos procedimientos por el juzgado de violencia sobre la mujer. Distingue, a estos efectos, entre dos hipótesis, en función de que la demanda civil presentada ante el juez de primera instancia sea anterior o posterior a la presentada, con idéntica pretensión, ante el juzgado de violencia sobre la mujer. Considero, aunque el autor citado no lo indica expresamente, que, para la determinación de la antigüedad habrá que estar a las normas generales previstas en el artículo 79.2 LECiv, el cual, a efectos de la consideración de cuál es el proceso más antiguo en los casos de acumulación, establece que la antigüedad se determinará por la fecha de la presentación de la demanda. Si las demandas se hubiesen presentado el mismo día, se considerará más antiguo el proceso que se hubiera repartido primero. Si por pender ante distintos tribunales, o por cualquier otra causa, no fuera posible determinar cuál de las demandas fue repartida en primer lugar, la solicitud podrá pedirse en cualquiera de los procesos cuya acumulación se pretende.

Hechas estas precisiones, analizaremos los dos supuestos planteados por el autor mencionado, las soluciones por él apuntadas y las consideraciones personales al respecto.

\subsection{SuPUeSto EN EL QUE UNA DE LAS PARTES INTERPONE LA DEMANDA CIVIL} ANTE EL JUZGADO CIVIL ORDINARIO CON POSTERIORIDAD A LA PRESENTACIÓN DE LA DEMANDA, CON IDÉNTICA PRETENSIÓN, POR LA OTRA PARTE ANTE EL JUZGADO DE VIOLENCIA SOBRE LA MUJER

La solución apuntada para este caso consistiría en invocar la excepción de litispendencia ante el órgano jurisdiccional civil, con el consiguiente sobreseimiento de las actuaciones, dado que ya existe un proceso civil previo con idéntico objeto ante el juzgado de violencia sobre la mujer que tiene competencia exclusiva y excluyente sobre él. En este sentido, considera necesaria la inclusión de una previsión en tal sentido en el artículo 49 bis LECiv, de modo que acreditada ante el juzgado civil ordinario la pendencia ante el JVSM de un procedimiento idéntico iniciado por una demanda ante-

102 Ontiveros Rodríguez, F., «Competencia civil de los Juzgados de Violencia sobre la Mujer: el art. 49 bis de la Ley de Enjuiciamiento Civil (problemática y propuestas de reforma)», cit., p. 1834. 
rior, aquel pudiera dictar sin más auto de sobreseimiento del procedimiento de que conoce, iniciado por una demanda posterior. El propio autor reconoce que la solución apuntada no está exenta de crítica, máxime si se tiene en cuenta que las excepciones han de resolverse en la vista ${ }^{103}$.

En mi opinión, en el supuesto planteado, y partiendo de que en el momento en que se interpuso la demanda civil ante el juzgado de violencia sobre la mujer concurrían todos los presupuestos para la atribución de competencia objetiva a este órgano, no estamos ante un problema de litispendencia, sino de falta de competencia objetiva del órgano civil (juzgado de primera instancia ordinario o especializado) para conocer de la demanda presentada, lo que determinaría la nulidad de las actuaciones practicadas ante él. Entraría en juego la exigencia del control de oficio de la competencia objetiva por parte del juez, previa audiencia de las partes y del Ministerio Fiscal, de acuerdo con lo dispuesto en el artículo 48.3. ${ }^{\circ}$ de la Ley de Enjuiciamiento Civil ${ }^{104}$.

Al margen del control de oficio, el carácter imperativo de las normas de competencia objetiva permite que su falta sea alegada por las partes mediante la interposición de la declinatoria.

\subsection{SuPUESTO EN EL QUE LA DEMANDA ANTE EL JUZGADO CIVIL SE PRESENTÓ CON ANTERIORIDAD A LA IDÉNTICA PRESENTADA ANTE EL ÓRGANO ESPECIA- LIZADO}

En este caso, OnTIVEROS RodRíGuez ${ }^{105}$, partiendo de la competencia exclusiva y excluyente del juzgado de violencia sobre la mujer considera que a este último siempre habrá de acumularse (bien vía inhibición por el juzgado de primera instancia bien vía requerimiento de inhibición por el propio juzgado de violencia sobre la mujer) el procedimiento del que conoce el órgano civil, y ello, a su juicio, con independencia de que este último fuese más antiguo ${ }^{106} \mathrm{y}$ de que en la mayor parte de este tipo de procesos sea posi-

${ }^{103}$ Ontiveros Rodríguez, F., «Competencia civil de los Juzgados de Violencia sobre la Mujer: el art. 49 bis de la Ley de Enjuiciamiento Civil (problemática y propuestas de reforma)», cit., p. 1834.

${ }^{104}$ Dispone el artículo $240.2 .^{\circ}$ LOPJ que «... el juzgado o tribunal podrá, de oficio o a instancia de parte, antes de que hubiere recaído resolución que ponga fin al proceso, y siempre que no proceda la subsanación, declarar, previa audiencia de las partes, la nulidad de todas las actuaciones o de alguna en particular».

${ }^{105}$ Ontiveros Rodríguez, F., «Competencia civil de los Juzgados de Violencia sobre la Mujer: el art. 49 bis de la Ley de Enjuiciamiento Civil (problemática y propuestas de reforma)», cit., pp. 1834 y 1835 .

106 Téngase en cuenta que, de acuerdo con las normas generales de la Ley de Enjuiciamiento Civil, «la acumulación de procesos se solicitará siempre al tribunal que conozca del proceso más antiguo, al que se acumularán los más modernos. De incumplirse este requisito, el tribunal inadmitirá la solicitud por auto y sin ulterior recurso» (art. 79.1 LECiv). 
ble la reconvención ${ }^{107}$, y de que en este último proceso se hubiera superado el límite temporal de la fase del juicio oral en el caso de que se solicite al juzgado de violencia sobre la mujer que requiera de inhibición al Juzgado civil. El propio autor expone los inconvenientes que esta solución comporta, y señala literalmente que «piénsese en los abusos procesales a que puede dar lugar esta laguna legal (además de la posible alteración de la competencia territorial), sobre todo porque la parte demandante ante JVSM, a pesar de haber interpuesto con posterioridad su demanda, se coloca en posición aventajada desde el punto de vista procesal; por ejemplo, en el caso de que en el proceso civil inicial ante el juzgado de primera instancia a la parte femenina le ha transcurrido, sin hacerlo, el plazo para contestar a la demanda o reconvenir (entre otras la pensión compensatoria) y antes de notificarle la rebeldía y citarla a la vista (o incluso con posterioridad) esta denuncia un acto de violencia de género ante el juzgado especializado, que da lugar al inicio de un proceso penal (lo que será la tónica general si por lo menos queremos oír al sujeto denunciado), para a continuación interponer ella una nueva demanda ante este último, al que además solicita que efectúe el requerimiento de inhibición a aquel otro órgano jurisdiccional». De ahí que, concluye el referido autor, «para evitar abusos maliciosos y desafueros sería conveniente que el legislador introdujera en el art. 49 bis LEC una previsión que en cierto modo otorgara "preeminencia procesal" al procedimiento iniciado con la demanda más antigua».

En mi opinión, no es necesaria dicha previsión expresa, sino que la solución debe venir dada en este supuesto por la aplicación de lo ya dispuesto en el artículo 49 bis de la Ley de Enjuiciamiento Civil. En este sentido, hay que partir de que, en el caso que estamos analizando, el juzgado civil era competente para conocer de la demanda civil en el momento en que se planteó, ya que todavía no se daban los presupuestos previstos en el artículo 87 ter LOPJ para la asunción por el juzgado de violencia sobre la mujer del conocimiento del procedimiento civil correspondiente. Una vez incoado el proceso penal correspondiente, por alguna de las infracciones previstas en dicho precepto, entrarían en juego las posibilidades previstas en el artículo 49 bis (inhibición por el juzgado de primera instancia o requerimiento de inhibición por el juzgado de violencia sobre la mujer) que parten, en todo caso, de la validez de las actuaciones llevadas a cabo hasta el momento por el juez civil. Considero, por tanto, que el procedimiento civil que debería seguir tramitándose, ahora ante un órgano distinto, es el iniciado ante el juzgado de primera instancia.

Por lo que se refiere al límite temporal para la inhibición a favor del Juzgado de violencia sobre la mujer, en coherencia con lo expuesto hasta el momento, entiendo que debería ser el de la celebración de la vista en el juicio civil iniciado con anterioridad.

${ }^{107}$ Cfr. artículo 78.2 LECiv. 


\section{Competencia funcional}

Una vez que el juzgado de violencia sobre la mujer asume la competencia para conocer de un concreto proceso de familia, dicha competencia se extenderá a todas su tramitación, incluyendo la fase declarativa y la ejecución ${ }^{108}$, así como los incidentes que se planteen ${ }^{109}$.

En este sentido, establece el apartado cuarto del artículo 82.1. ${ }^{\circ} \mathrm{LOPJ}$, añadido por el artículo 45 de la LO 1/2004, «de los recursos que establezca la Ley contra las resoluciones en materia penal dictadas por los Juzgados de Violencia sobre la Mujer de la provincia. A fin de facilitar el conocimiento de estos recursos, y atendiendo al número de asuntos existentes, deberán especializarse una o varias secciones de conformidad con lo previsto en el artículo 98 de la citada Ley Orgánica. Esta especialización se extenderá a aquellos supuesto en que corresponda a la Audiencia Provincial el enjuiciamiento en primera instancia de asuntos instruidos por los Juzgados de Violencia sobre la Mujer de la provincia».

Por otro lado, en virtud de lo dispuesto en el artículo 545.1 LECiv que dispone que «será competente para la ejecución de resoluciones judiciales y de transacciones y acuerdos judicialmente homologados o aprobados el tribunal que conoció del asunto en primera instancia o el que homologó o aprobó la transacción o acuerdo», el juzgado de violencia sobre la mujer será competente para la ejecución de todas aquellas resoluciones que haya dictado en asuntos civiles.

Comparto, por otro lado, con base en dicho precepto, el criterio de PÉREZ-OLLEROS ${ }^{110}$ en cuanto a la falta de competencia funcional del Juzgado

${ }^{108}$ Vid. LiBAno Beristain, Arantza, «La competencia de los juzgados de violencia sobre la mujer y su incidencia en la ejecución civil», Manuel CACHÓN CADENAS, Joan PICÓ I JunOY (coords.), La ejecución civil: problemas actuales, Atelier, Barcelona, 2008, pp. 281 a 314.

${ }^{109}$ Siendo la Jura de Cuenta un proceso dependiente del que trae su causa, su conocimiento corresponderá al juzgado, civil o de violencia sobre la mujer, que conoce del pleito de derecho de familia en el que se suscite. En este sentido señala la Audiencia Provincial de Madrid (sección 18.a), en el Auto de 21 de diciembre de 2007, rec. 773/2007, que «no siendo la Jura de Cuenta un proceso autónomo, sino dependiente del principal del que trae causa, no es dable dividir su conocimiento y resolución, entre dos órganos judiciales. Máxime, cuando la atribución indebida de la competencia para su conocimiento a un Juzgado ajeno a aquel que tramita el procedimiento principal civil, de derecho de familia, privaría a este Juzgado del conocimiento sobre los necesarios antecedentes, que en dicho pleito principal obran, y que son necesarios para la resolución de la Jura de Cuenta. En consecuencia, al no poder sino entenderse el procedimiento de Jura de Cuenta, como un incidente del pleito principal del que trae causa, su conocimiento no puede sino atribuirse al Juzgado de Violencia contra la Mujer, ... que conoce del pleito de derecho de familia, del que es incidente dicha Jura de Cuenta».

${ }^{110}$ PÉrez-Olleros SÁnchez-Bordona, Francisco Javier, «Cuestiones y respuestas sobre la Ley Orgánica de Medidas de Protección Integral contra la Violencia de Género», cit., p. 1839; En el mismo sentido, OnTIVERos RodríGuEZ, F., «Competencia civil de los Juzgados 
de violencia sobre la mujer para la ejecución de lo ya resuelto en un procedimiento civil por un órgano civil (juzgado de familia o de primera instancia), sin perjuicio de que corresponda la ejecución al juzgado de violencia sobre la mujer si ha dictado la sentencia en el procedimiento civil, ya que, como señala el referido autor «los procedimientos de ejecución forzosa a que se refiere el art. 776 de la LEC no tienen por objeto la adopción o modificación de medidas, y porque la regla es que corresponde el conocimiento de la ejecución de lo resuelto al Juez que resolvió en primera instancia (arts. 61 y 545.1 y 776 LEC), sin perjuicio de las labores de apoyo que puedan prestar los servicios comunes que al efecto se constituyan, y salvo especialización en Juzgados de ejecución con arreglo a lo dispuesto en el art. 98 de la LOPJ».

Por último, ante la falta de mención expresa, se ha cuestionado la inclusión del procedimiento de liquidación del régimen económico matrimonial, regulado en el Capítulo II del Título II del Libro IV de la Ley de Enjuiciamiento Civil, en el listado del punto 2 del artículo 87 ter de la Ley Orgánica del Poder Judicial.

Con carácter general, considero que la respuesta debe ser negativa por ser una interpretación extensiva no prevista en la ley ${ }^{111}$, si bien esta postura debe matizarse por lo dispuesto en el artículo 807 LECiv, el cual, poniendo fin a las dudas suscitadas al amparo de la Ley de Enjuiciamiento Civil en cuanto al órgano competente para conocer de la liquidación ${ }^{112}$, establece que «será competente para conocer del procedimiento de liquidación el Juez de primera instancia que esté conociendo o haya conocido del proceso de nulidad, separación o divorcio, o aquel ante el que se sigan o hayan seguido las actuaciones sobre disolución del régimen económico matrimonial por alguna de las causas previstas en la legislación civil» ${ }^{113}$.

de Violencia sobre la Mujer: el art. 49 bis de la Ley de Enjuiciamiento Civil (problemática y propuestas de reforma)», cit., p. 1835; CASTILlEJo MANZANARES, Raquel, «Cuestiones que suscita la Ley Orgánica de Medidas de Protección Integral contra la Violencia de Género», cit., p. 2030.

${ }^{111}$ PÉREZ-Olleros SÁnChEZ-Bordona, Francisco Javier, «Cuestiones y respuestas sobre la Ley Orgánica de Medidas de Protección Integral contra la Violencia de Género», cit., p. 1839.

${ }^{112}$ Vid. en relación con la situación anterior a la Ley de Enjuiciamiento Civil 1/2000, Montes Reyes, Amalia, División Judicial de patrimonios, La Ley, Madrid, 2000, pp. 147 y ss.

${ }^{113}$ Se trata de un precepto coherente con lo dispuesto en artículo 61 LECiv, el cual, salvo disposición legal en otro sentido, atribuye al tribunal competente para conocer de un pleito la competencia funcional para resolver sobre sus incidencias, para llevar a efecto las providencias y autos que dictare, y para la ejecución de la sentencia o convenios y transacciones que aprobare, ya que nos encontramos ante uno de los aspectos de la ejecución de la sentencia. Montes ReYes, Amalia, División Judicial de patrimonios, La Ley, Madrid, 2000, pp. 154 y 155 . 
El precepto transcrito parte de la posibilidad de que la disolución del régimen económico matrimonial sea consecuencia de la sentencia dictada en un proceso matrimonial o haya sido declarada en un proceso declarativo específico para la disolución del régimen económico, ordinario o verbal según la cuantía del patrimonio, con base en alguno de los supuestos previstos en el artículo 1.393 del Código Civil ${ }^{114}$. Este tipo de procedimientos quedan fuera del listado relacionado en el apartado $2 .^{\circ}$ del artículo 87 ter LOPJ y, por tanto, en estos casos, por aplicación de lo dispuesto en el artículo 807 LECiv, deberá conocer de la liquidación del régimen económico matrimonial el órgano civil -juzgado de primera instancia o juzgado de familia- que hubiera conocido del proceso declarativo civil.

Sin embargo, cuando la liquidación sea como consecuencia de la disolución del régimen a que da lugar la sentencia de separación, nulidad o divorcio y esta haya sido dictada por un juzgado de violencia sobre la mujer, ese mismo artículo 807 LECiv debe conducir a considerar que corresponderá a este juzgado el conocimiento del procedimiento para la liquidación del régimen económico matrimonial ${ }^{115}$. Así, lo dispone, el Auto de la Audiencia Provincial de Valencia, Sección 10. ${ }^{\text {, }}$ de 29 de mayo de 2008, rec. $403 / 2008^{116}$ al señalar que «el hecho de que el artículo 87 de la Ley Orgánica del Poder Judicial no precise esta competencia entre las de orden civil que corresponden a estos Juzgados no impide que se considere que la tienen por conexión, determinada por el artículo 807 de la Ley de Enjuiciamiento Civil; esta atribución de competencia es además más coherente con el propósito de la Ley Orgánica 1/2004 (...), que pretende, como su título indica, una protección de la mujer frente a la violencia doméstica lo más completa posible, y en consecuencia, es claro que esa protección debe extenderse a un proceso como el de liquidación del régimen económico matrimonial, que es consecuencia directa del proceso que regula las consecuencias de la crisis conyugal».

\section{La competencia territorial}

La competencia territorial de los juzgados de violencia sobre la mujer viene determinada por la norma establecida en el artículo 15 bis de la Ley de Enjuiciamiento Criminal, adicionado por el artículo 59 de la LO 1/2004, el

${ }^{114}$ Cfr. artículos 1.393, 1.392, 1.373 y 1.415 del Código Civil.

115 PÉreZ-Olleros SÁncheZ-Bordona, Francisco Javier, «Cuestiones y respuestas sobre la Ley Orgánica de Medidas de Protección Integral contra la Violencia de Género», cit., p. 1832.

${ }^{116}$ Se pueden consultar en este sentido, además de las resoluciones citadas en este auto, los Autos de la Audiencia Provincial de Vizcaya, Sección 4. ${ }^{\text {a }}$, de 15 de diciembre de 2006, rec. 725/2006 y de 26 de enero de 2007, rec. 674/2006. 
cual, en relación con los delitos y faltas cuya instrucción o conocimiento corresponda a estos órganos exceptúa la regla general del lugar de comisión del hecho (forum delicti comissi), y establece como fuero el lugar del domicilio de la víctima, sin perjuicio de la posible adopción de la orden de protección, o de medidas urgentes del artículo 13 LECrim $^{117}$ por el juez de instrucción de guardia del lugar de comisión de los hechos, si fuera distinto al de la residencia habitual, lo cual acontecerá en aquellos supuestos en los que la pareja esté ya separada de hecho o judicialmente.

El cambio de criterio respecto al general en estos supuestos se introduce con la finalidad de facilitar el acceso de la víctima al órgano judicial, aunque pudiera plantear algunas cuestiones en caso de sucesivos cambios de domicilio o de provisionalidad de este.

En principio, para determinar cuál es el domicilio de la víctima, habrá que estar a lo dispuesto en el artículo 40 del Código Civil que establece que el domicilio de las personas naturales será el lugar de su residencia habitual $^{118}$.

En los casos en los que la víctima no tenga una residencia fija ${ }^{119}$, habrá de establecerse cuál es el lugar en el que reside de forma más continuada y con mayor arraigo y, a estos efectos, a partir de la declaración de la propia víctima, debería procederse a una comprobación por parte del órgano judicial, a efectos de contrastar que esta está corroborada por otros datos (domicilio que figure en el DNI, datos del padrón, domicilio fiscal...), a efectos de impedir que pueda elegir el órgano encargado de la instrucción de los hechos ${ }^{120}$.

${ }^{117}$ El artículo 13 LECrim considera como primeras diligencias «la de consignar las pruebas del delito que puedan desaparecer, la de recoger y poner en custodia cuanto conduzca a su comprobación y a la identificación del delincuente, la de detener, en su caso, a los presuntos responsables del delito, y la de proteger a los ofendidos o perjudicados por el mismo, a sus familiares o a otras personas, pudiendo acordarse a tal efecto las medidas cautelares a las que se refiere el artículo 544 bis o la orden de protección prevista en el artículo 544 ter de esta ley».

${ }^{118}$ De acuerdo con lo dispuesto en el artículo 70 del Código Civil, «los cónyuges fijarán de común acuerdo el domicilio conyugal y, en caso de discrepancia, resolverá el Juez, teniendo en cuenta el interés de la familia».

${ }^{119}$ Para los casos en los que la víctima desarrolle su vida en dos poblaciones distintas, MARTínEZ GARCía considera que «habrá que optar por aquel en el que tenga mayor arraigo, estimando en caso de duda como fuero preferente el que coincida con el lugar de comisión de los hechos» (MARTínez GARCíA, Elena, La tutela judicial de la violencia de género. op. cit., p. 116).

${ }^{120}$ En este sentido, considera ARMENTEROS LEÓN, que «una primera diligencia básica en este tipo de procedimientos será la de oficiar a los organismos correspondientes a fin de averiguar el domicilio de la víctima, ello salvo que resulte notorio y sea innecesario lo anterior» (ARmenteros León, Miguel, «Algunas cuestiones que plantea la competencia de los nuevos Juzgados de Violencia sobre la Mujer», cit., D-10). 
Una de las cuestiones que suscitó la aplicación del precepto que analizamos fue la relativa a qué momento debía atenderse para determinar el domicilio de la víctima. Cuestiones prácticas podrían aconsejar que fuera el de la interposición de la denuncia. Este criterio es más acorde con la finalidad perseguida con el establecimiento del fuero legal del artículo 15 bis LECrim, de facilitar el acceso de la víctima al órgano judicial.

Sin embargo, se ha establecido que habrá que estar al lugar del domicilio de la víctima, no en el momento de interponer la denuncia, sino en el momento en que ocurren los hechos punibles, y son intrascendentes los cambios posteriores que pudiera llevar a cabo. En este sentido, el Auto del Tribunal Supremo (Sala 2. ${ }^{\mathrm{a}}$, Sección 1.a) de 3 de marzo de 2006 (EDJ 2006/3725) señala que «esta decisión ha sido sometida a un Pleno no jurisdiccional de esta Sala (...) celebrada el día 31 de enero de 2006 y ha acordado que por domicilio de la víctima habrá que entender el que tenía cuando se produjeron los hechos punibles, en cuanto responde mejor al principio de Juez predeterminado por la Ley, no dependiendo de posibles cambios de domicilio y es el criterio que coincide con lo expuesto por el Ministerio Fiscal, aplicando el mantenido por la Circular 4/2005, de la Fiscalía General del Estado».

Esta solución puede hacer frustrar la finalidad referida en aquellos casos, que pueden ser frecuentes, en los que la víctima, precisamente huyendo de su agresor, haya cambiado de domicilio tras la perpetración de los hechos, antes de proceder a denunciarlos. Sin embargo, pese a ese inconveniente, se ha considerado que este criterio garantiza en mayor medida el derecho al juez ordinario predeterminado por la ley, evitando la designación del órgano judicial por el perjudicado ${ }^{121}$.

Este criterio no es suficiente para resolver los supuestos en los que los hechos objeto de la causa ocurrieron unos cuando la víctima tenía un domicilio y otros, cuando tenía otro distinto. Ante un caso de este tipo la Audiencia Provincial de Guipúzcoa, Sección 1. ${ }^{\text {a }}$, en el Auto de 2 de julio de 2007 (rec. 1230/2007), partiendo de que la ratio legis de la norma parece ser la de procurar que los hechos se instruyan y sean enjuiciados por un órgano judi-

${ }^{121}$ En este sentido se señala en el Auto del Tribunal Superior de Justicia de Cataluña, Sección 1. a, de 20 de noviembre de 2006, rec. 72/2006, que «es cierto que la realidad diaria demuestra que en sucesos como el que ha dado lugar al presente procedimiento, las víctimas se ven obligadas con frecuencia a poner tierra de por medio con sus agresores antes incluso de denunciar los hechos, realidad que, teniendo en cuenta el interés de la víctima, obligaría a deferir la competencia en tales supuestos al órgano judicial en cuyo partido se estableciera el nuevo domicilio y en el que se formalizara la denuncia, pero no lo es menos que un criterio de esta naturaleza podría dejar a voluntad de una de las partes la fijación del fuero competencial, e incluso de alterarlo tantas veces cuantas considerara necesario o simplemente conveniente cambiarlo, lo que pugna con la concepción de esta materia como propia del orden público y por lo tanto indisponible». 
cial próximo al domicilio de la víctima, en beneficio de esta, a fin de acercarle dicho órgano, para facilitar su acceso a este, concluye que «en casos como el que nos ocupa, en los que la víctima tuvo dos domicilios distintos mientras ocurrieron los hechos objeto de la causa y no quepa apreciar que el traslado tuviera como objeto elegir el órgano competente, dicha finalidad solo se cumpliría si dicho órgano competente fuera, de entre el correspondiente a dichos dos domicilios, el del domicilio actual».

Por último, hay que mencionar que, en los casos excepcionales en los que no se pueda determinar el juez territorialmente competente por no poder concretarse el domicilio de la víctima, por encontrarse en el extranjero o no tener domicilio conocido, se estará al lugar en el que se encuentre residiendo aun con carácter accidental y, en su defecto, serán de aplicación los fueros generales previstos en los artículos 14 y 15 de la LECrim, con carácter subsidiario ${ }^{122}$.

En este sentido, para un caso en el que el delito se ha cometido en territorio español pero el domicilio habitual de la víctima se encuentra en Irlanda, el Auto de la Audiencia Provincial de Tarragona, Sección 4. ${ }^{a}$, de 18 de septiembre de 2006 (rec. 731/2006), señala que «en estos supuestos es obvio que la jurisdicción española es competente para el conocimiento de los hechos (art. 23 LOPJ), y que las reglas de competencia territorial establecidas en la Ley de Enjuiciamiento Criminal únicamente resuelven la competencia entre órganos jurisdiccionales españoles del mismo orden». Por ello, continúa, «en aquellos supuestos en los que el domicilio de la víctima se encuentra en el extranjero o es desconocido, bien porque se carezca de él, o no se haya podido averiguar, dado que los Tribunales españoles siguen siendo competentes, deberá resolverse la atribución de competencia, que siempre ha de corresponder a un órgano jurisdiccional español, en función del domicilio que accidentalmente tenga la víctima en territorio español, o como último criterio subsidiario, por el lugar de comisión de los hechos».

La vis atractiva del juzgado de violencia sobre la mujer que conoce del asunto penal en relación con el proceso civil supone que el fuero penal atraerá la competencia territorial para conocer de dicho proceso civil, dejando sin efecto las normas de atribución de competencia territorial previstas en la Ley

${ }^{122}$ El Auto de la Audiencia Provincial de Girona, Sección 4. ${ }^{\text {a }}$, de 17 de septiembre de 2007 , rec. 433/2007, en un supuesto en el que de las actuaciones no puede decidirse a ciencia cierta cuál es el domicilio, establece que «no existiendo entonces un lugar en el que poder fijar de momento el domicilio de la perjudicada, sin perjuicio de que este extremo pueda aclararse en el futuro, podemos acogernos para la determinación de la competencia territorial a los criterios fijados por el art. 15 de la Ley de Enjuiciamiento Criminal, que dispone para el caso de que no conste el lugar en el que se haya cometido el delito o falta, lo que a nuestros efectos vendría a significar que no pueda determinarse con seguridad el domicilio de la víctima en un supuesto de violencia sobre la mujer, una cascada de posibilidades». 
de Enjuiciamiento civil. Por tanto, en los casos en los procedimientos civiles que son de la competencia exclusiva y excluyente de los juzgados de violencia sobre la mujer, se produce una alteración de las normas de atribución de competencia territorial de los artículos 769 y 779 LECiv, así como del fuero previsto por el art. 51 LECiv en los supuestos de demandas que tengan por objeto la oposición a las resoluciones administrativas en materia de protección de menores y, por tanto, dirigidas contra la entidad pública. 